Article

\title{
Navigations for Hospitality Human Resource Management Research: Observing the Keywords, Factors, Topics under the COVID-19 Pandemic
}

\author{
Jue Wang ${ }^{1}\left(\mathbb{D}\right.$, Hyun-Jeong Ban ${ }^{1}$, Hyun-Woo Joung ${ }^{2}$ and Hak-Seon Kim ${ }^{3,4, *(\mathbb{D})}$ \\ 1 School of Global Studies, Kyungsung University, Busan 48434, Korea; wangjue@ks.ac.kr (J.W.); \\ helenaban@ks.ac.kr (H.-J.B.) \\ 2 Department of Nutrition and Hospitality Management, The University of Mississippi, \\ Oxford, MS 38677, USA; hjoung@olemiss.edu \\ 3 School of Hospitality \& Tourism Management, Kyungsung University, Busan 48434, Korea \\ 4 Wellness \& Tourism Big Data Research Institute, Kyungsung University, Busan 48434, Korea \\ * Correspondence: kims@ks.ac.kr
}

check for updates

Citation: Wang, J.; Ban, H.-J.; Joung, H.-W.; Kim, H.-S. Navigations for Hospitality Human Resource Management Research: Observing the Keywords, Factors, Topics under the COVID-19 Pandemic. Information 2022, 13, 126. https://doi.org/

$10.3390 /$ info13030126

Academic Editor: Symeon

Papadopoulos

Received: 16 January 2022

Accepted: 1 March 2022

Published: 2 March 2022

Publisher's Note: MDPI stays neutral with regard to jurisdictional claims in published maps and institutional affiliations.

Copyright: () 2022 by the authors Licensee MDPI, Basel, Switzerland. This article is an open access article distributed under the terms and conditions of the Creative Commons Attribution (CC BY) license (https:// creativecommons.org/licenses/by/ $4.0 /)$.

\begin{abstract}
The hospitality industry is one of the most affected by the pandemic, and because of its human close interaction and labor-intensive characteristics, it has left Human Resource Management (HRM) puzzles with organizations' stabilization and recovery. This study aimed to summarize current research on hospitality HRM research outcomes and trends during the COVID-19 pandemic. Utilizing the PRISMA technique and NVivo software, 102 research articles were extracted and analyzed to highlight to overall achievement and movement of hospitality HRM research under the shadow of the COVID-19 crisis. Considering the main purpose of this study, which was to show the status and prospects, the findings indicated 309 free nodes and 26 secondary nodes based on grounded theory. 7 key themes clustered from the analysis and include "environmental factors", "industrial factors", "HRM practice", "organization", "employee", "external outcomes", and "methodology". The results demonstrated the COVID-19 pandemic driven HRM transformation. In addition, it sheds light on how research responds to the shifting navigation of HRM within the hospitality context under the COVID-19 conditions.
\end{abstract}

Keywords: COVID-19; hospitality industry; hospitality HRM; grounded theory; NVivo

\section{Introduction}

The new coronavirus disease (COVID-19) has swept the earth rapidly, alarming and shaking the predominantly offline operated industry. Instead, industries with a solid foundation of information technology and automation have stronger resilience to cope with the crisis. For instance, in the manufacturing industry, business operations have been negatively impacted, while revenue growth has occurred in the online gaming industry. More obviously, the education industry is taking steps to seek ways to move from its offline to online operations [1].

Among these industries, the hospitality industry looked to be on the cusp of the pandemic [1]. This is because of its sensitivity to political and economic instability, pandemics, disasters, public incidents [2]. The overall inevitability and seemingly insurmountable obstacles appear in hotels [3], foodservices [4,5], bars [6], and other hospitality businesses [7]. To cope with pandemic influences, the hospitality industry may have to adopt more innovative practices.

Along with the external marketing environment challenges, the internal marketing environment of the hospitality industry has changed radically simultaneously. As a serviceproviding industry, the linkage between internal and external marketing is essential for the hospitality industry. HRM places great emphasis on providing employees and external 
customers with the preconditions for satisfaction. HRM should take the helm and develop capabilities to face the unprecedented changes. Many scholars have shown concern for a re-assessment of HRM because of the contextual backdrop [8]. For instance, several scholars have called for a greater focus on employee nature. The concept of "people-based" or "people-powered" has reappeared on the protagonist stage under the pandemic [9]. Another critical recurring theme is organizational health and safety risks [10]. Furthermore, researchers proposed leading-edge concepts such as HR co-creation [11], agile HR [12], flexible working arrangements [13], requiring more studies on HR strategy and practice. The existing trends and crises have also driven various HRM disciplines across borders. There is still a lack of research on hospitality HRM resilience and reaction facing the crisis era. Specifically, a research gap exists when it comes to providing crossroads and mega-trends within hospitality HRM.

In light of these challenges, the study aimed to (1) explore the published paper status in the hospitality HRM field under the COVID-19 pandemic; (2) extract the keywords and themes concerning hospitality HRM within the COVID-19 pandemic environment; (3) propose research directions related to hospitality HRM and the COVID-19 pandemic. In accordance with previous research exploring thematic context within hospitality HRM, this study utilized the PRISMA flow technique to ensure reliable data collection progress [14]. Instead of applying text mining for bibliometric analysis and topic modeling for qualitative data analysis, this study employed the NVivo approach for thematic analysis as advocated by Braun and Clarke, 2006 [15].

\section{Literature Review}

\subsection{Hospitality Industry and Crisis}

Although the boundaries are difficult to define, the hospitality industry generally refers to enterprises that provide entertainment, travel distribution channels, travel accommodation, and foodservices for travelers [16]. Scholars have outlined four main approaches to describe the nature of hospitality, they are professionalism, hospitableness, experience, and philosophy [17]. Due to the immense scale of the industry, which has grown to include theme parks, airlines, cruise ships, trade shows, fairs, and gaming as well [18], the hospitality industry has become one of the world's most significant and essential employers [19].

The hospitality industry has been most affected and threatened by crises and disasters $[1,20,21]$. How the industry responded to the crisis and disasters is a crucial area of research concern. For instance, Chien and Law, 2003 [22] addressed the risk identification, assessment, and alleviation based on the SARS crisis. Wen, Huimin, and Kavanaugh, 2005 [23] conducted a survey investigating SARS's impact on Chinese tourists. Kim, Chun, and Lee, 2005 [24] examined the Korean hotel industry for evidence on crisis management. Lee, Song, Bendle, Kim, and Han, 2012 [25] investigated how the H1N1 virus affected potential travelers' decision-making processes. Hung, Mark, Yeung, Chan, and Graham, 2018 [26] developed a case study focused on published guidelines in Hong Kong regarding SARS and H1N1. They described how the hospitality industry is responding to the pandemic. Park, Kim, and Choi, 2019 [27] reported communication environment of social media context changes before and during the Irma hurricane. The authors developed an analytical framework that emphasizes the role of influential actors.

The hospitality industry is facing a superimposed challenge under the pressure of the COVID-19 crisis. For the sake of minimizing the unfavorable wreckage on the hospitality industry due to crisis, scholars tried to offer strategies for surviving even development for hospitality on dry land. Alan, So, and Sin, 2006 [28] laid stress on the need reduce investment and increase negotiation under SARS background. Using a hybrid of humans and machines, Pillai, Haldorai, Seo, and Kim, 2021 [29] boosted Hospitality 5.0 by ensuring hygiene operations and safe accessibility to touchpoints under the COVID-19 pandemic. Im, Kim, and Miao, 2021 [30] noted while reviewing other specific strategies involved, such as restructuring and layoffs, reducing costs and saving cash, changing the way services are delivered, and complying with updated standards but the loss of profits. Moreover, 
scholars utilized big data analysis to point out delivery, no-touch, and online shopping emerging as the leading trends for foodservices [4]. Similarly, Mun, Ban, and Kim, 2020 [5] mentioned the new concept sand products emerging due to rapid changes in the hospitality industry in the pandemic era. Thus, there is a need to revise the situation of the hospitality industry and verify the drivers of successful recovery paths in the COVID-19 crisis [20].

\subsection{Hospitality HRM}

The most widely used definition of human resource management is the one defined by Snell and Bohlander, 2010 [31] which describes it as a process for managing human capital to achieve the organization's goals. The hospitality industry is a labor-intensive industry, and this feature provides an excellent research environment for exploring HRM issues. In addition to having essential and practical HR functions, such as integrating resources, managing employees, cultivating capabilities, formulating strategies, improving performance, and achieving organizational goals, hospitality HRM also needs to assist the hotel industry in providing high-quality services to customers and maintaining customer relationships, moreover, promoting core competencies while the pursuit of organizational success. In addition to this, the people in the hospitality sector include both employees and customers. Therefore, HRM for hospitality is recognized as a critical element for connecting customers and transforming services, building core competencies, and improving internal and external performance [32].

In hospitality HRM research, the content analysis approach has been observed for decades. A literature review by Guerrier and Deery, 1998 [33] based on 156 publications about hospitality industry HRM research, evaluates the status of hospitality HRM research. The researchers summarized their findings in a multilevel mechanism: marketing, organizational, and employee level. Singh, Hu, and Roehl, 2007 [34] conducted a qualitative research on the development progress (1994-2003) of hospitality HRM literature and proposed nine major HRM research aspects including hospitality career, training, satisfaction, intention, legal and compliance, gender differentiation, work environment, personal development, performance evaluation. Most recently, scholars have suggested HRM practices, turnover intention or behavior, employee and customer satisfaction, conflict, flexible working, wellbeing, and firm performance have been the dominant aspects of past research [35]. Herbie, Illés, Dunay, and Khalife, 2021 [36] conducted a bibliometric analysis of the tourism and hospitality sector's HRM based on publications from 1977 to 2020 . Through analysis, they identified "citizenship behavior and migration workers" as the latest engaging topics. Wang, Dagvadorj and Kim, 2021 [37] brought forward trends of hospitality HRM research through a sample of Korean Citation Index (KCI) publications. In terms of the seven topics, hospitality jobs, relationships, and performance, customers, and services account for the highest ratio.

The existing research mainly reveals the influence of the pandemic on the global economy and workforce market. Moreover, it begins to dig into the movements and creativeness of the HR field with different industries in the post-pandemic contexts. To limit the challenges in the hospitality industry, the HRM department must quickly respond to this new environment.

\subsection{Grounded Theory and NVivo}

This study explored the qualitative content analysis method. Content analysis is an in-depth, systematic analysis of a phenomenon lacking theoretical knowledge of the relevant materials, material coding, classification, aggregation, statistics, and ultimately the formation of specific knowledge of flexible research methods [38]. Braun and Clarke, 2006 [15] mentioned the momentum of widespread adoption of grounded theory when the thematic analysis is required. An operation process consists of reading the description material of a phenomenon lacking theory verbatim, encoding the description material, clustering the coding based on the similarity, affiliation, and related relationship between the coding, and then using the coding to measure the material, and then summarizing 
the knowledge of that phenomenon. It is suitable for in-depth analysis and systematic induction of text materials and has significant advantages in describing the main features of a phenomenon for expanding and enriching existing theoretical knowledge.

Grounded theory [39] is widely used in many social science fields, which emphasizes the systematic collection and analysis of empirical facts and the theory of sampling based on empirical facts. According to grounded theory, boundary questions, data search and collection, data analysis and coding, and theoretical model construction are four steps for processing. This paper strictly followed the steps. First, to clarify the research process, this study recognized the need to understand the main question: what is the current research status of hospitality HRM under the COVID-19 crisis? What factors in the context influence the antecedents-HRM-performances mechanism?

Next, NVivo 12.0 software was developed by QSR as an analysis tool for coding data and organizing nodes for qualitative research, which is certified as a package approach to implementing grounded theory [40]. It is relevant to recognize that NVivo can display grounded theory in multiple facets, even the final step of showing the explanatory model accompanied by a depth of understanding $[40,41]$. Many scholars conducted research and contributed to hospitality-related issues with the aid of NVivo [42-44]. NVivo makes it possible to import and analyze rich amounts, large sizes, and different types of qualitative data [41]. The process in NVivo includes developing a project, importing documents, coding the node, and conceptualizing the attributes. Entangled in this process, scholars could link the different groups of the data, create and collate the node structure, and visualize and model the data [41].

\section{Methodology}

\subsection{Software Selection}

Scholars emphasized the need to choose effective tools for qualitative research from a wide range of technologies [45]. Figure 1 outlines the research approach and each selected software. To put this in order, this study incorporated the Web of Science (WoS) database, allowing advanced searches and export of the file, which included an overview of the paper, title, abstract, and keywords [45]. In order to ensure that the report's accuracy and reliability, this study imported PRISMA 2020 [14] and followed its guidance to modify or remove the data. PRISMA flow can be used as the basis of reporting systematic reviews, which benefits in providing a clear and complete process, thereby facilitating reliability [14].

Once the review and citation reports are conducted, VOSview free software [46] creates maps based on text corpus co-occurrence matrix. VOSview is widely implemented because of its high-quality visualization and powerful big data processing capabilities $[45,46]$. The next step involves data organizing, a three-step coding method, and refining the topic, and NVivo 12.0 was applied at this stage. NVivo is user-friendly, and the internal operating structure is very flexible $[41,45]$. First, open coding was conducted to break down data into units and determine and mark cluster concepts $[39,47]$. The second step in the coding process is to use the axial coding function to classify important nodes and data into outlines $[39,47]$. The third coding step is to associate related topics (or themes) and subtopics (or subthemes) through selective coding $[39,47]$. Overall, this study followed the conceptual logic of grounded theory $[39,47]$ and, based on the theoretical model of the strategic role of HRM for organizations [31,32] conducted the analysis. 


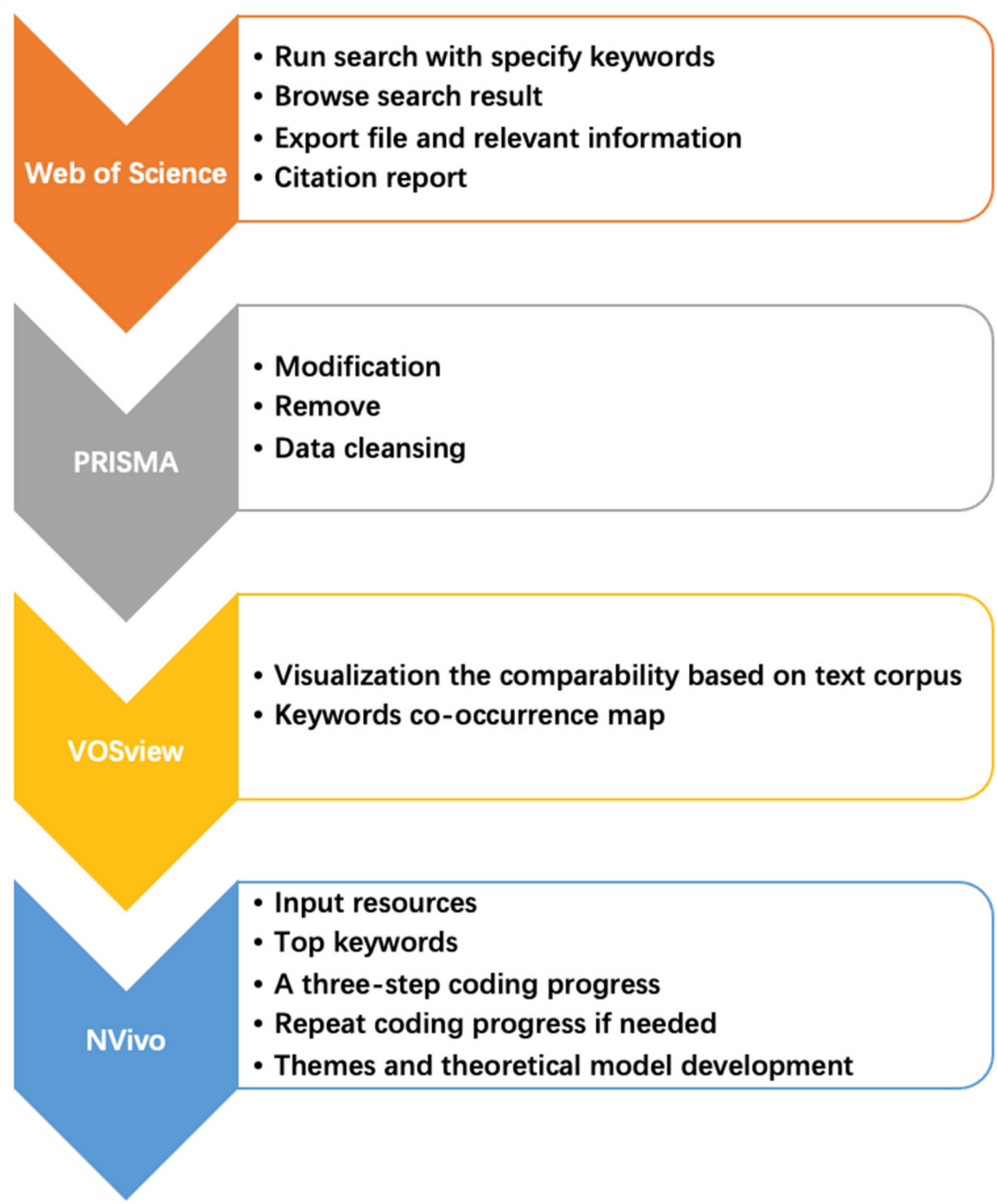

Figure 1. Outlined a step-by-step research design.

\subsection{Procedure}

To extract papers that relate to hospitality HRM, "hospitality", "employee", "COVID19", and "human resource" were entered as the keywords in the WoS database. This study developed a selection strategy for reporting systematic reviews based on the PRISMA flow chart mode [14]. As shown in Figure 2, three consecutive steps, including identification, screening, and inclusion, were procedures. The search result returned 96 articles and 46 related sources (retrieved on 10 November 2021). Then these publications are thoroughly screened. As part of this, we first checked the research area of the sample. Less relevant research areas (such as computer science) were excluded. To further ensure the validity of the data, the title, abstract, and keywords of each publication were analyzed [48]. Finally, publications are discarded because of non-English writing $(\mathrm{n}=7)$, unable to download original text $(n=26)$, invalidity $(n=4)$, non-research paper $(n=3)$, and 40 articles are excluded. The final 102 publications sample is listed in Table A1 in Appendix A. 


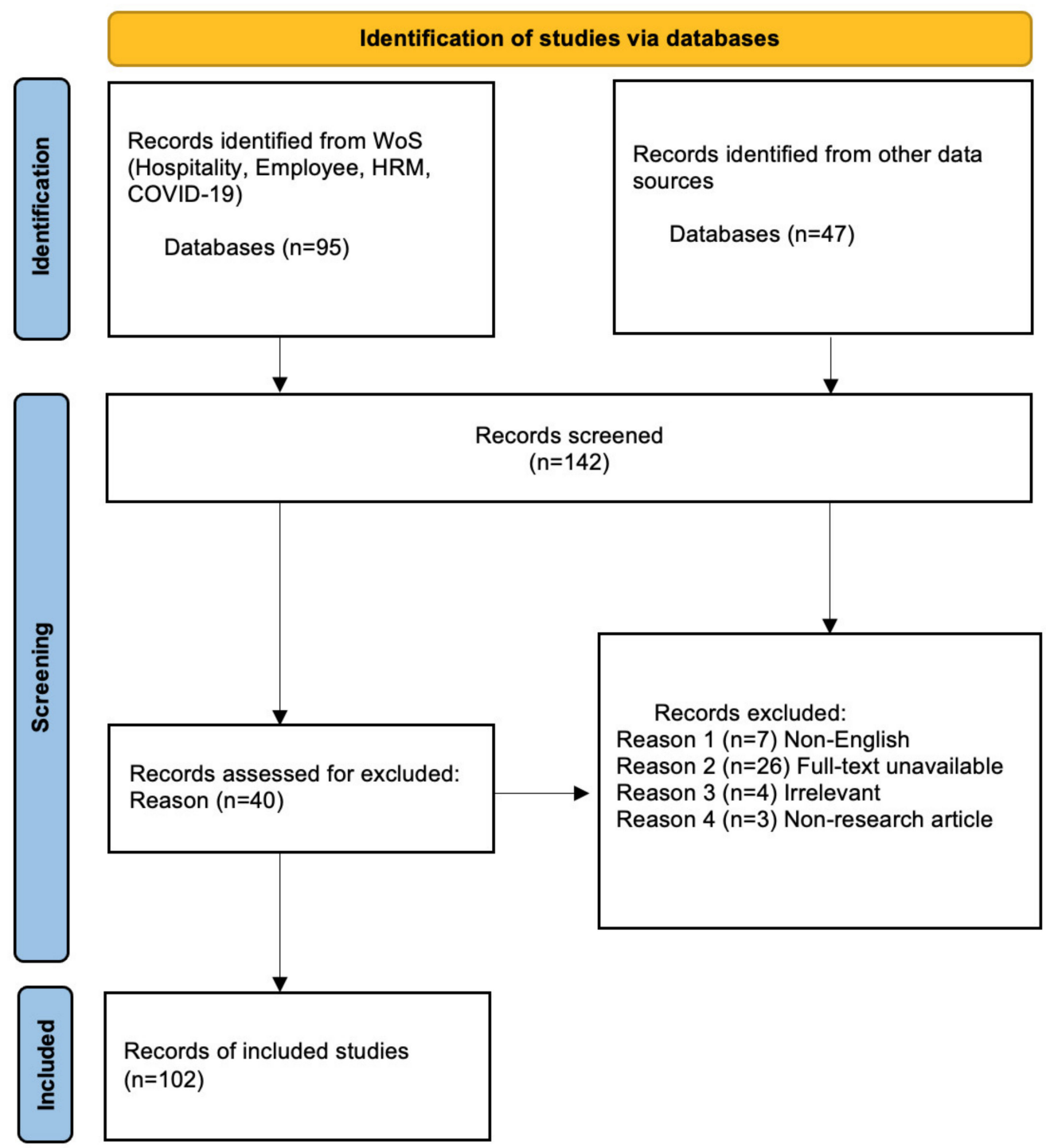

Figure 2. PRISMA flow diagram for selection strategy.

\section{Results}

\subsection{Overview of Publications}

Figure 3 displays the publication and citation report between the years 2020 and 2021. Overall, 102 articles with the topic COVID-19 and hospitality HRM were examined in this study. 84 articles $(82.3 \%)$ were published in 2021 . The citation rate ballooned to almost 17 times from 2020 to 2021. Specifically, the highest cited paper (total citation $=156$ ) is the paper "COVID-19's impact on the hospitality workforce-new crisis or amplification of the norm?" conducted by Baum, Mooney, Robinson, and Solnet, 2020 [49]. It can be observed that the growth of academic interests, also reflected the urgent research necessity from the side.

Table 1 lists the research areas of publications. The top 10 research areas are concentrated on hospitality leisure sport tourism, management, environment science, green sustainable science technology, environmental studies, business, public environmental occupational health, economics, business finance, sociology, and area studies. 


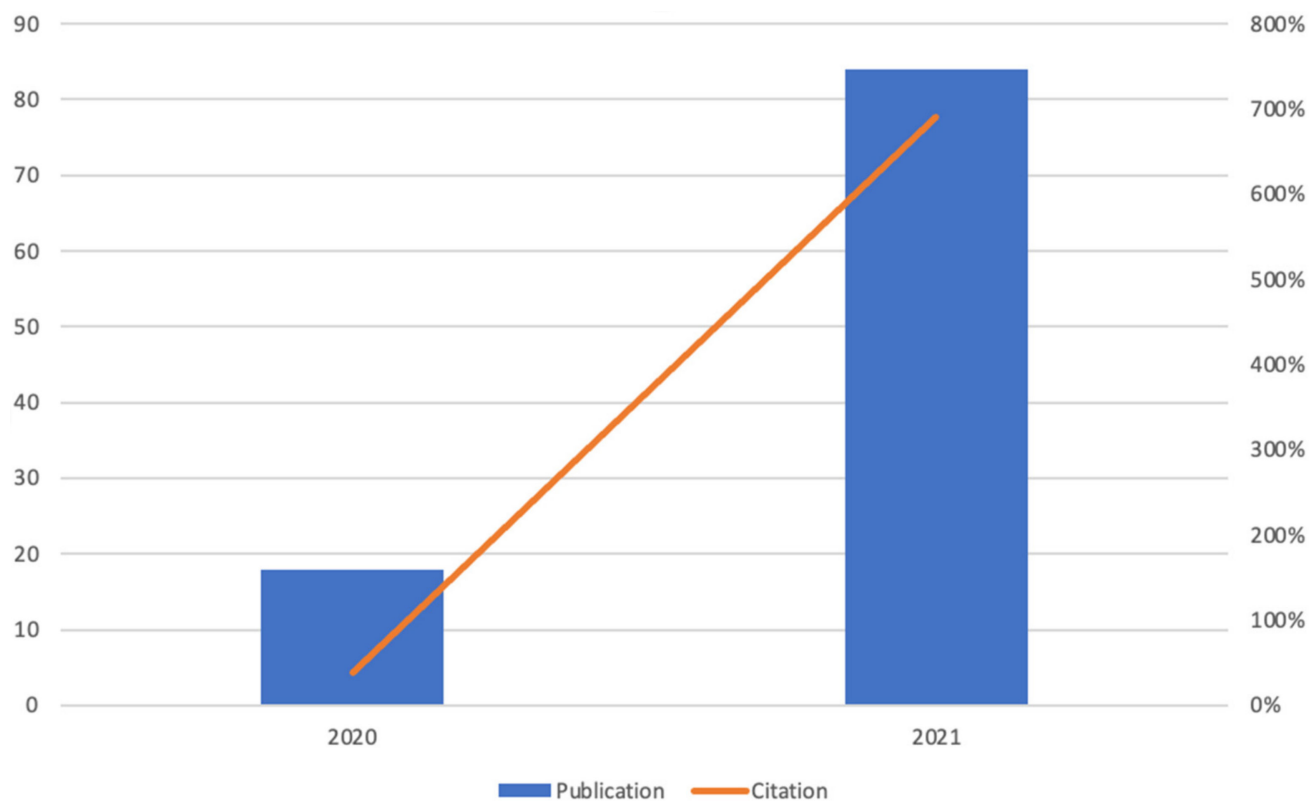

Figure 3. Time cited and publications over time.

Table 1. Top 10 research areas of publications.

\begin{tabular}{ccc}
\hline Field: Research Areas & Record Count & \% of 102 \\
\hline Hospitality Leisure Sport Tourism & 64 & 62.745 \\
Management & 24 & 23.529 \\
Environmental Science & 10 & 9.804 \\
Green Sustainable Science Technology & 8 & 7.843 \\
Environmental Studies & 7 & 6.863 \\
Business & 6 & 5.992 \\
Public Environment Occupational Health & 5 & 4.902 \\
Economics & 3 & 2.941 \\
Business Finance & 2 & 1.961 \\
Sociology & 2 & 1.961 \\
Area Studies & 1 & 0.980 \\
\hline
\end{tabular}

\subsection{Keywords and Co-Occurrence Analysis}

In order to extract accurate keywords, this study only uses the title, keywords, and abstracts for word frequency analysis. Table A2 (Appendix B) listed the top 100 words. "employee" (433 count, 2.02\% weighted), "covid" (310 count, 1.44\% weighted), "hotel" (239 count, 1.11\% weighted) and "hospitality" (235 count, 1.09\% weighted), "working" (207 count, $0.96 \%$ weighted) appeared. There are also some keywords shown exciting clues, such as "health" (207 count, 0.96\% weighted), "employed" (120 count, $0.56 \%$ weighted), "mental" (78 count, $0.36 \%$ weighted). "responsibility" (74 count, $0.34 \%$ weighted), "customer" (64 count, $0.30 \%$ weighted), "resilience" (61 count, $0.28 \%$ weighted), "safety" (57 count, $0.27 \%$ weighted), "insecurity" (57 count, $0.27 \%$ weighted), "stress" (57 count, $0.27 \%$ weighted), "home" (56 count, $0.26 \%$ weighted), "change" (50 count, $0.23 \%$ weighted), and "risk" (50 count, $0.23 \%$ weighted). Figure 4 shows the top 100 frequency words cloud. 


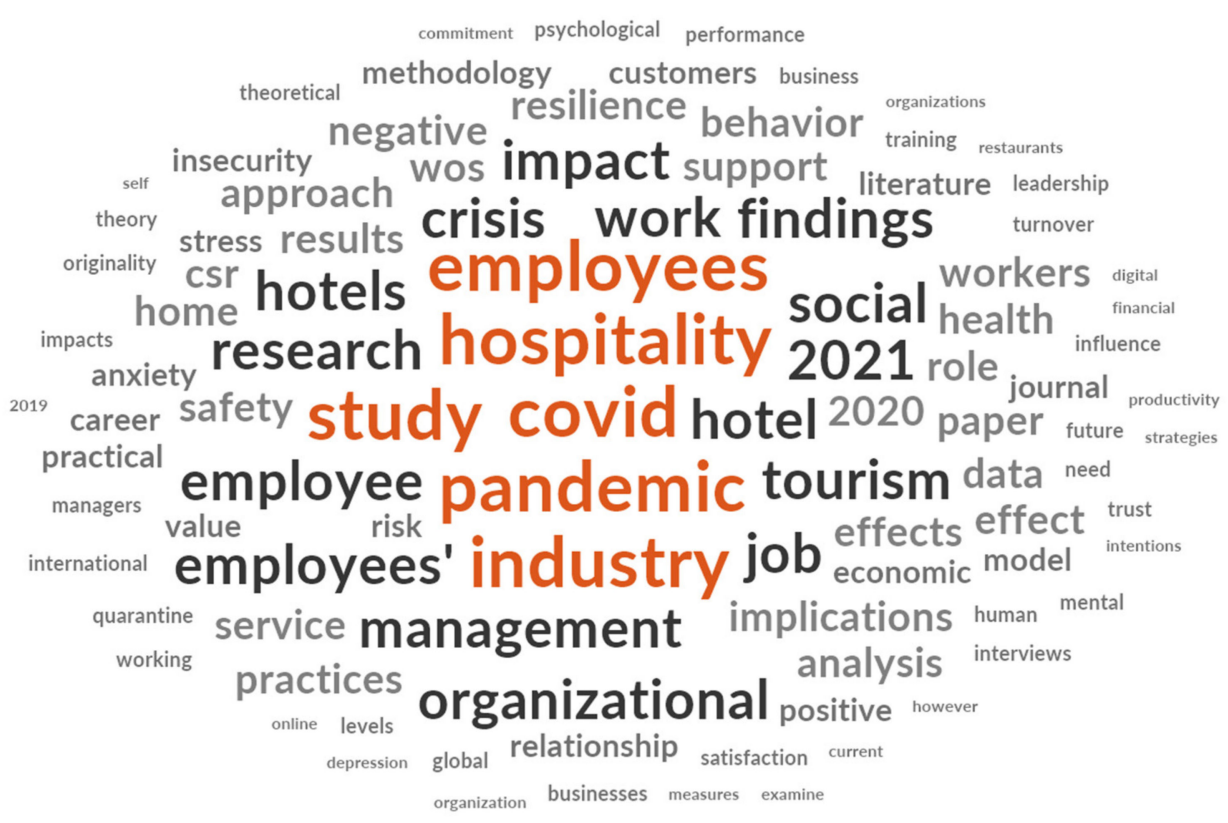

Figure 4. Word cloud 100.

This study utilized the visualization tool VOSviewer to produce Keyword co-occurrence analysis [46]. Figure 5 visualizes the keywords co-occurrence map. The red cluster and green cluster are in the center of the network, which also shows that the theme frequently appeared recently. These themes can be considered as consequences of employees in the hospitality and the COVID-19 contexts, such as turnover intention, layoff, and emotional challenge. The yellow cluster consists of terms related to the hospitality field organizational performance with COVID-19. In addition, the blue cluster includes terms that marginal and edge themes, such as research methodology and demographic characteristics.

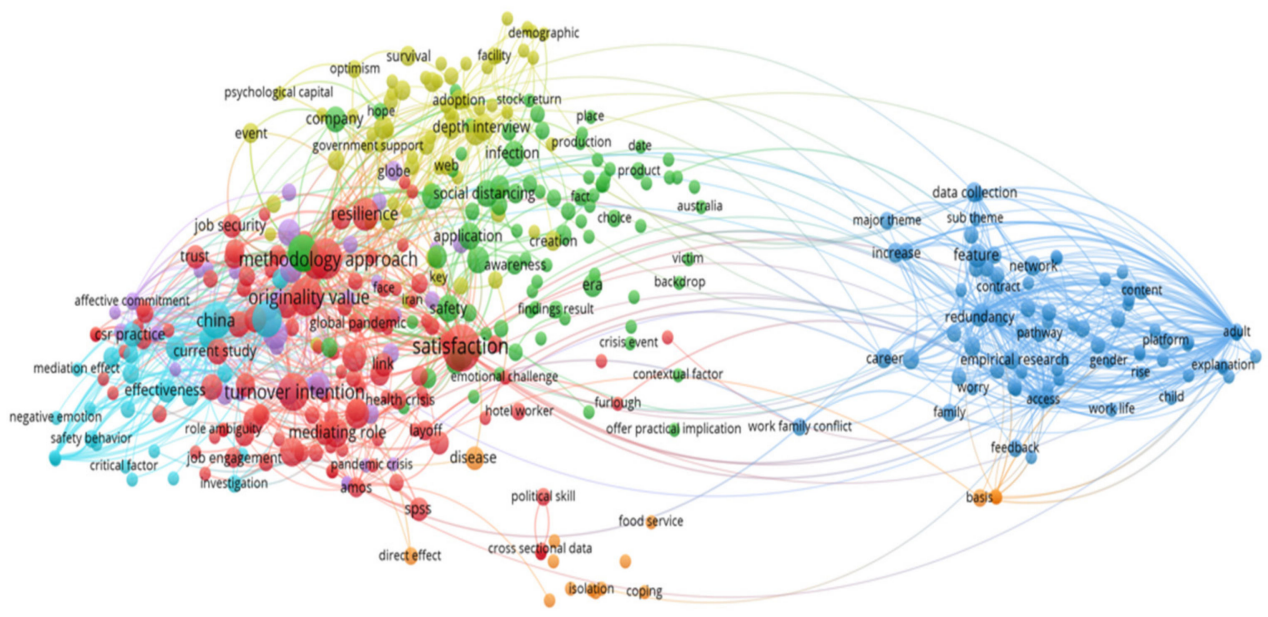

\& vosviewer

Figure 5. Keywords co-occurrence map. 


\subsection{Coding Process}

After preliminary data processing and analysis, this study adopted the qualitative data analysis method generally advocated by scholars based on the NVivo technique [15,41] First, after running open code, this study totally obtained 309 nodes (see Figure 6).

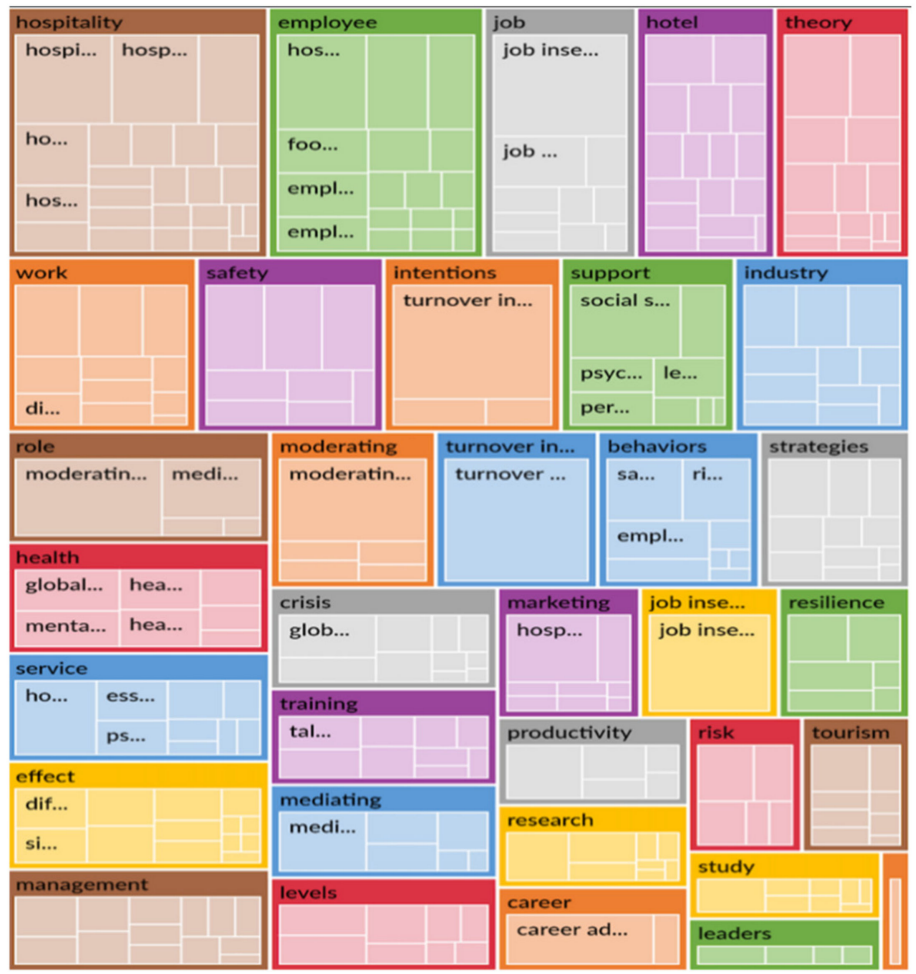

Figure 6. 309 free codes cluster map.

The secondary code is a further induction and integration based on the 309 nodes. This study obtained 26 secondary nodes "behaviors", "career", "crisis", "effect", "employee", "health", "hospitality", "hotel", "industry", "intention", "job", "job insecurity", "leaders", "levels", "management", "marketing", "mediating", "moderating", "productivity", "research", "resilience", "risk", "role", "safety", "service", "social responsibility", "strategies", "study", "support", "theory", "tourism", "training", "turnover intention". Based on these secondary codes, the top 10 clusters represent the relationship between the COVID-19 and the hospitality industry, while the pandemic is closely linked to hotel employees (see Figure 7).

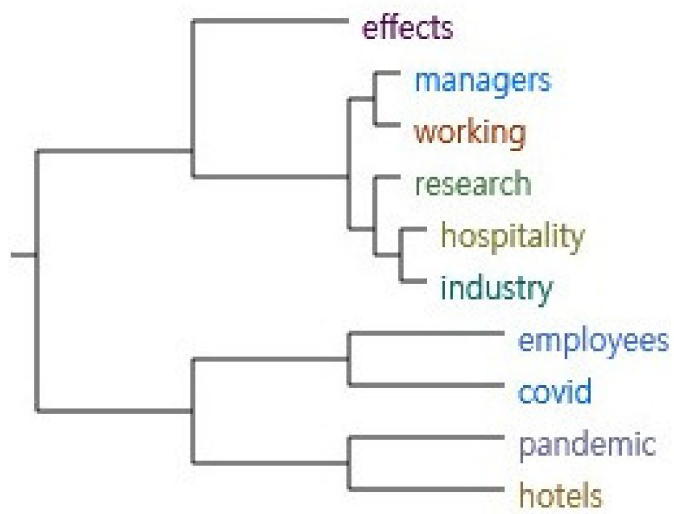

Figure 7. Top 10 clusters. 
While open coding leads to searching for themes [15,41], the process of reviewing themes should include re-coding the nodes. This study reorganized the 309 free codes and 26 secondary codes into seven major categories, or themes, namely, "industrial factor", "environmental factor", "employee", "organization", "external outcomes", "HRM practice", and "methodology". Figure 8 presents the nodes structures. The center is the purpose of the paper, that is, the research of hospitality HRM and the specific hierarchy of hospitality HRM research in the background of the COVID-19 pandemic is expressed in a multi-layered ring. The internal nodes of each layer of the ring are divided into dimensions that reflect the dimensions or categories of hospitality HRM research with COVID-19.

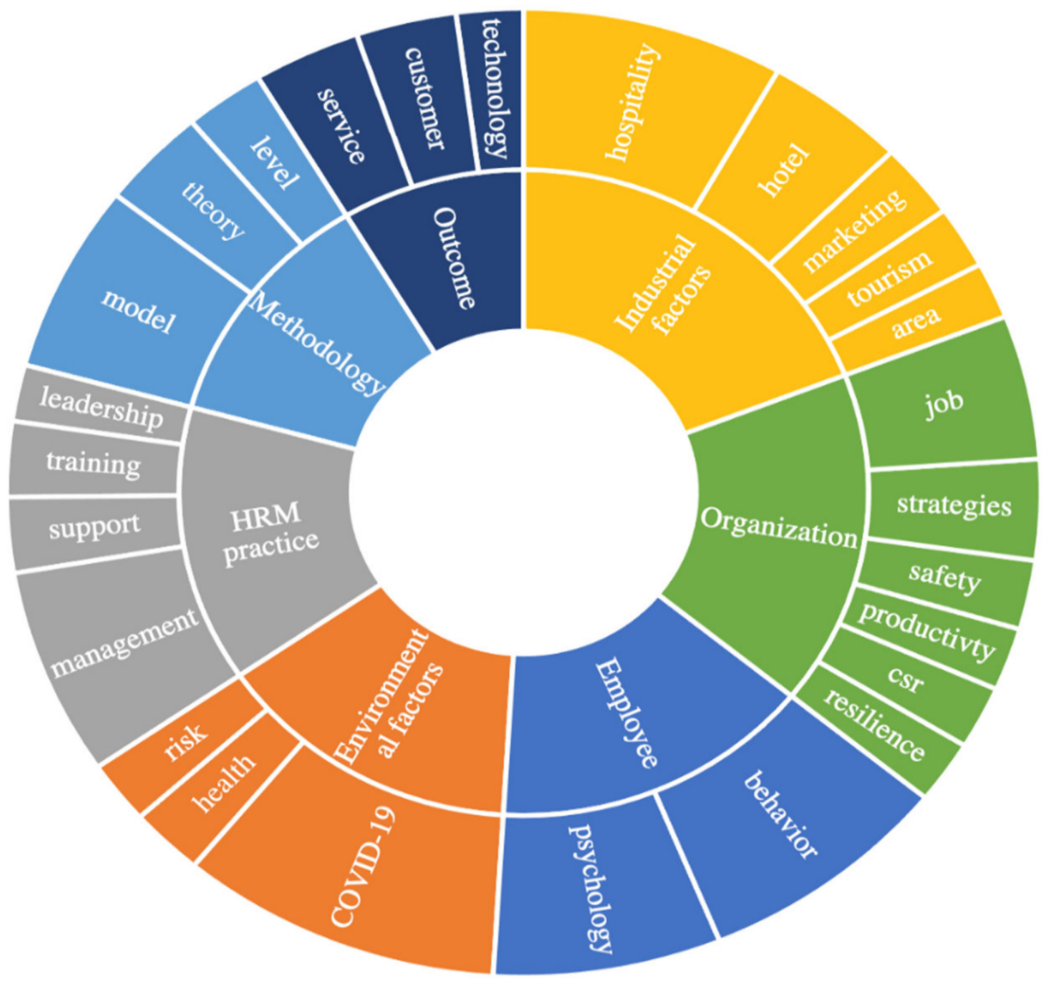

Figure 8. Nodes' structure.

From the structures of the nodes, it can be seen that the influencing variables of hospitality HRM and COVID-19 are comprised of seven main themes and 26 secondary nodes. The vertical structure of the circle in each sector area reflects the hierarchical relationship of the specific variables of the hospitality HRM research in the context of COVID-19, due to a large number of tertiary nodes, only the themes and the secondary nodes obtained by NVivo [15] encoding are listed in this figure. Accordingly, the size of the sectoral area of each layer is determined by the number of reference points in the code, which represent the number of documents supporting each node, reflecting the influence of a particular factor on all the influencing elements of this layer. Among seven main themes, the "industrial factor" and "organization" account for the most references, reflect the most attention and influence. The order that follows is "employee" and "environmental factors". It also illustrates from the side that the hospitality industry is a labor-centered industry. A surprising finding is the presence of "methodology" nodes. Scholars tested the different concept of "theory", multiple "levels", and the various of "model" around the topic of hospitality HRM and COVID-19. However, the slightly regrettable finding is that there is not much research on the "external outcomes", as the quality of "service", "consumption", and "customer satisfaction". Perhaps because of the COVID-19 pandemic, studies that observe or investigate such substantive manifestations and performances could not be conducted. 


\subsection{Conceptual Network}

The grounded theory advises scholars to exercise concepts and develop a theoretical model construction [15,39]. In doing so, the final step of analysis is developing a theoretical model construction [15,39]. This study attempted to investigate factors relationships by applying the seven separate themes to the conceptual strategic HRM role model [31,32] and Input-Process-Output (IPO) mechanism. Tables 2-8 presents the detailed description of themes and factors, which blends discovered themes and factors into existing concepts, thus integrating them into a more formidable theoretical framework.

Table 2. Nodes for "environmental factors".

\begin{tabular}{|c|c|c|}
\hline Theme: Environmental & Node Count & Example Nodes (Numb. of Points) \\
\hline Environmental factors & 40 & \\
\hline COVID-19 & 25 & $\begin{array}{c}\text { crisis management }(1) \\
\text { crisis preparedness }(1) \\
\text { crisis responses }(1) \\
\text { extraordinary crisis situation }(1) \\
\text { global crisis }(2) \\
\text { global health crisis }(10) \\
\text { pandemic crisis }(10)\end{array}$ \\
\hline Health & 9 & $\begin{array}{c}\text { health crisis }(1) \\
\text { additional health }(1) \\
\text { health complaints }(1) \\
\text { health risk (4) } \\
\text { mental health problems (2) }\end{array}$ \\
\hline Risk & 6 & $\begin{array}{c}\text { risk perception }(1) \\
\text { health risk }(2) \\
\text { home risks }(1) \\
\text { risk reduction strategies (1) } \\
\text { various risks (1) }\end{array}$ \\
\hline
\end{tabular}

Table 3. Nodes for "industrial factors".

\begin{tabular}{|c|c|c|}
\hline Theme: Industrial & Node Count & Example Nodes (Numb. of Points) \\
\hline Industrial factors & 59 & \\
\hline Tourism & 10 & $\begin{array}{l}\text { domestic tourism }(1) \\
\text { food tourism }(1) \\
\text { fragile tourism (1) } \\
\text { tourism industry (3) } \\
\text { tourism organizations (2) } \\
\text { tourism sector (1) } \\
\text { tourism workforce }(1)\end{array}$ \\
\hline Area & 5 & $\begin{array}{l}\text { Canadian lodging industry (1) } \\
\text { Indian hospitality industry (1) } \\
\text { Taiwanese tourism (1) } \\
\text { Chinese hospitality industry (1) } \\
\text { Egypt (1) }\end{array}$ \\
\hline Hotel & 18 & $\begin{array}{c}\text { boutique hotel }(1) \\
\text { chain-managed five-star hotels }(5) \\
\text { hotel industry }(8) \\
\text { Lebanese hotels }(1) \\
\text { multinational hotel corporation experience (1) } \\
\text { robot-staffed hotels (1) } \\
\text { rural hotels (1) } \\
\text { subsidiary hotel properties (1) }\end{array}$ \\
\hline
\end{tabular}


Table 3. Cont.

\begin{tabular}{|c|c|c|}
\hline Theme: Industrial & Node Count & Example Nodes (Numb. of Points) \\
\hline Hospitality & 25 & $\begin{array}{c}\text { hospitality industry (12) } \\
\text { hospitality sectors (5) } \\
\text { hospitality context (2) } \\
\text { industry revival (1) } \\
\text { large-scale industry transformation (1) } \\
\text { private equity industry (1) } \\
\text { service industries (1) } \\
\text { multinational hospitality companies (2) }\end{array}$ \\
\hline Marketing & 10 & $\begin{array}{c}\text { stock markets (1) } \\
\text { changing marketing channels (2) } \\
\text { competitive market (1) } \\
\text { hospitality services marketing structure (4) } \\
\text { market adjustment (1) } \\
\text { transformative marketing structure (1) }\end{array}$ \\
\hline
\end{tabular}

Table 4. Nodes for "HRM practice".

\begin{tabular}{|c|c|c|}
\hline Theme: HRM Practice & Node Count & Example Nodes (Numb. of Points) \\
\hline HRM practice & 41 & \\
\hline Training & 11 & $\begin{array}{c}\text { certificate training }(1) \\
\text { employee training }(1) \\
\text { crisis awareness training }(1) \\
\text { confidence-building training }(2) \\
\text { contemporary training }(1) \\
\text { innovative training }(1) \\
\text { talent cultivation training (3) } \\
\text { safety coaching }(1)\end{array}$ \\
\hline Support & 12 & $\begin{array}{c}\text { community support }(2) \\
\text { income support }(2) \\
\text { personal support networks }(1) \\
\text { psychological support services }(1) \\
\text { religious support }(1) \\
\text { social support }(2) \\
\text { supervisor support }(3)\end{array}$ \\
\hline Management & 16 & $\begin{array}{c}\text { crisis management (4) } \\
\text { human resource management (11) } \\
\text { impression management tactics (1) } \\
\text { management safety practices (1) }\end{array}$ \\
\hline Leadership & 2 & $\begin{array}{l}\text { leader conscientiousness (1) } \\
\text { hotel safety leadership (1) }\end{array}$ \\
\hline
\end{tabular}

Table 5. Nodes for "influence on employee".

\begin{tabular}{|c|c|c|}
\hline Theme: Employee & Node Count & Example Nodes (Numb. of Points) \\
\hline Employee level & 54 & \\
\hline Behavior & 26 & $\begin{array}{c}\text { employee withdrawal behavior (3) } \\
\text { human behavior (1) } \\
\text { instilling servant behaviors (1) } \\
\text { prompting safety behaviors (1) } \\
\text { risk-taking behavior (2) } \\
\text { safety performance behaviors (2) } \\
\text { work behavior (1) } \\
\text { career adaptability (7) } \\
\text { employee productivity (5) } \\
\text { employee empowerment (2) } \\
\text { employee entitlements (1) }\end{array}$ \\
\hline
\end{tabular}


Table 5. Cont.

\begin{tabular}{|c|c|c|}
\hline Theme: Employee & Node Count & Example Nodes (Numb. of Points) \\
\hline Psychology & 28 & $\begin{array}{c}\text { aggregation (1) } \\
\text { career change intention (4) } \\
\text { turnover intention (10) } \\
\text { employee anxiety (1) } \\
\text { employee fears (3) } \\
\text { employee focus (1) } \\
\text { employee loyalty (4) } \\
\text { employee wellbeing (2) } \\
\text { psychological resilience (1) } \\
\text { psychological support services (1) }\end{array}$ \\
\hline
\end{tabular}

Table 6. Nodes for "influence on organization".

\begin{tabular}{|c|c|c|}
\hline Theme: Organization & Node Count & Example Nodes (Numb. of Points) \\
\hline Organizational level & 59 & \\
\hline Job & 30 & $\begin{array}{c}\text { building job satisfaction (2) } \\
\text { job shadows (2) } \\
\text { job creation (1) } \\
\text { job destruction rates (1) } \\
\text { job insecurity (9) } \\
\text { job loss (9) } \\
\text { job motivation (4) } \\
\text { job performance (1) } \\
\text { prevented job destruction (1) }\end{array}$ \\
\hline Strategies & 10 & $\begin{array}{c}\text { organizational crisis strategies }(2) \\
\text { branding strategies }(2) \\
\text { corporate narrative strategies }(1) \\
\text { different information search strategies (1) } \\
\text { innovative strategies }(1) \\
\text { recovery strategy development }(1) \\
\text { risk reduction strategies }(2)\end{array}$ \\
\hline Resilience & 9 & $\begin{array}{l}\text { resilience factors (3) } \\
\text { organizational resilience (4) } \\
\text { resilience action (2) }\end{array}$ \\
\hline Safety & 4 & $\begin{array}{c}\text { organizational safety climate (2) } \\
\text { safety procedures (1) } \\
\text { safety regulations (1) }\end{array}$ \\
\hline CSR & 1 & social responsibility (1) \\
\hline Productivity & 5 & $\begin{array}{c}\text { pre-pandemic productivity trend (1) } \\
\text { productivity collapse }(1) \\
\text { productivity dynamics }(2) \\
\text { productivity growth (1) }\end{array}$ \\
\hline
\end{tabular}

Table 7. Nodes for "influence on service, customer, technology".

\begin{tabular}{ccc}
\hline Theme: Outcomes & Node Count & Example Nodes (Numb. of Points) \\
\hline Service, customer, technology & 18 & \\
\hline Service & 14 & $\begin{array}{c}\text { corporate service departments (4) } \\
\text { essential service workers (2) } \\
\text { personal services sectors (4) }\end{array}$ \\
\hline Customer & 3 & $\begin{array}{c}\text { re-visit intention (2) } \\
\text { consumption behaviors (1) }\end{array}$ \\
\hline Technology & 1 & service robots (1) \\
\hline
\end{tabular}


Table 8. Nodes for "methodology".

\begin{tabular}{|c|c|c|}
\hline Theme: Methodology & Node Count & Example Nodes (Numb. of Points) \\
\hline Research methodology & 34 & \\
\hline Model & 16 & $\begin{array}{c}\text { mediating mechanism (6) } \\
\text { moderating mechanism (8) } \\
\text { gender moderates }(1) \\
\text { double mediators }(1) \\
\text { chaos theory perspective }(1) \\
\text { event system theories }(1) \\
\text { expectancy-valence theory }(1) \\
\text { impression management theory }(1) \\
\text { learning theories }(1)\end{array}$ \\
\hline Theory & 12 & $\begin{array}{l}\text { occupational stigma theory }(1) \\
\text { proxemics theory }(1) \\
\text { resource allocation theories }(1) \\
\text { self-categorization theory }(1) \\
\text { social exchange theory }(1) \\
\text { stakeholder theory }(1) \\
\text { transactional theory }(1)\end{array}$ \\
\hline Level & 6 & $\begin{array}{c}\text { depression levels (1) } \\
\text { increasing levels (1) } \\
\text { individual level (1) } \\
\text { industry level (1) } \\
\text { social interaction levels (1) } \\
\text { team level (1) }\end{array}$ \\
\hline
\end{tabular}

\subsubsection{Theme 1: Input: Environmental Factors}

The first theme is "environmental factors". Scholars have executed many studies to illustrate how and why environmental factors may influence HRM practice so strongly $[31,50,51]$. In this study, environmental factors mainly refer to the COVID-19 crisis, which is an antecedent that affects the challenge of hospitality HRM. Scholars described how COVID-19 has shocked the hospitality industry. At the same time, it was also concerned with "health" and "risk".

\subsubsection{Theme 2: Input: Industrial Factors}

Industry and sector characteristics affect HRM activities in different ways [31,51]. "tourism", "hotel", "hospitality", and "marketing" have been identified. It is noteworthy that "robot-staffed hotels" began to surface and be seen as a remarkable current issue for the hospitality industry [52]. Bowen and Morosan, 2018 [52] provided their view of artificial intelligence (AI) in the hospitality industry and proposed its usage will be effective by the 2030s. Due to COVID-19, the age of AI and robotics in hospitality is coming sooner than expected. The two sides of $\mathrm{AI}$ and robotics, including positive and negative influences, are discussed [53-56].

\subsubsection{Theme 3: Progress: HRM Practice}

It is reasonable to assume that the COVID-19 crisis has triggered the issue related to the rethinking and recrafting of HRM strategies and practices in the hospitality sector. Compared to other topics and themes, it is obvious that scholars have paid limited attention to HRM practice. "Training", "support", "management", and "leadership" are most frequently explored by scholars. For leadership, only "hotel safety leadership" [57] has appeared in multigroup experimental analysis. There is a need for leaders to refine their perspectives on managing employees from a new angle. 


\subsubsection{Theme 4: Outcome: Influence on the Employee}

Scholars believed employees are the foundations of HRM, what is more worthy of mention is that the pandemic has brought people-oriented back to the focal point [9]. "Foodservice employees", "hospitality employees", and "service employees" are the group of people who are concerned and pointed out. Various variables have been investigated as employee performance. For example, some scholars explored employees' "mental health" and "mental problems" under the COVID-19 crisis [58,59]. Employee's work attitude and "turnover intention" [60-62], career adaptive [63], perspective on career prospect [64,65], risk perspective, well-being, anxiety, and stress [66,67]. It is not surprising how COVID-19 negatively affects hospitality employee work performance; scholars have tried to explore and explain the black box of how the COVID-19 crisis has affected hospitality staff through theoretical mechanisms.

\subsubsection{Theme 5: Outcome: Influence on the Organization}

"Organization" is a theme with a high proportion of weight, indicating that there are more nodes under this theme, and scholars' research attention and research outcomes are heightened. The challenge of coping with COVID-19 underlines the need for the organizations to revive their fading business dynamism. "job", "strategies", "resilience", "safety", "CSR", and "productivity" are the highlighted issues.

\subsubsection{Theme 6: External Outcome: Service, Customer, Technology}

Compared with influences on employee level and organizational level, "external outcomes" related to the external performance, factors such as "service", "customer", and "technology" are emphasized. The effectiveness of hospitality HRM is not only embodied in internal management and organizational performance but how to provide quality services to customers is also part of the responsibility [32].

\subsubsection{Theme 7: Methodology}

In the last theme, "Methodology", by way of example, "model" node was drawn with different mechanisms, whereas "theory" is seen as the theoretical background and logic support, with multiple perspectives of "level" research encapsulated in this theme.

\section{Agenda for Hospitality HRM}

The COVID-19 pandemic has seriously affected the political and economic development pattern in the world. It has profoundly changed the hospitality industry and human resource service mode of hospitality HRM. The normalization of pandemic prevention and control has brought revolutionary challenges to employees and employers. Through an in-depth analysis of the text of research on hospitality HRM during the pandemic period, this study offers the agenda faced by the development of research on hospitality HRM in the post-pandemic era.

The first issue is employee mental health. With the central concern of employees' positive behavior and psychological health, the hospitality industry should be concerned about employee anxiety, stress, nervousness, and negative turnover intention. Psychological assistance, training programs can be provided appropriately. Furthermore, strengthening leadership services and fostering an internal organizational environment for win-win cooperation are also vital.

The second issue relates to the working environment safety. To cope with the pandemic prevention and control crisis, it is time for business associations to establish comprehensive cleaning and safety standards for enterprises. Furthermore, to achieve a work environment in the negative pandemic situation, HRM for the hospitality sector must be rigorous and flexible. Employees in the hospitality sector are close interaction with guests, making them work at risk in the context of the pandemic. HRM should offer strict workflow and standard checklists to guarantee employees security. Furthermore, employees' intentions, such as risk perception, are in the chain of the work environment. The need to increase 
HRM flexibility in hospitality industry to promote workplace safety is more urgent than ever today.

The third issue involves the disruptive HRM practice. On the one hand, hospitality HRM is facing major development opportunities. Adapting to the changes in the human resource market and the needs of human resource services, disruptive and innovative HR practices are the outlet for problem-solving, which has triggered creative thinking about the HRM perspective. Based on the finding, this study suggests hospitality HRM (1) applying PopTech such as social media, big data, AI, and robotics, speeding up the digital transformation of human resource services, (2) organizational reconstruction and business model reconstruction, (3) enhancing the internationalization of human resource services, and (4) deepening the dialogue between stakeholders including industry, social, and government. These strategies will bring unlimited development space for the develop the hospitality human resource services industry.

The post-pandemic era has arrived, the fourth focus is on recovery and transition. As the hospitality industry develops and recovers in the post-pandemic era, it is crucial to concentrate on the particular problems faced by the transformation and development of market segments and specific HR practices in the background of hospitality and to provide theory and strategic support to HR departments at different levels and types of development planning. Back to our findings, resilience is the main key access point to enhance the organization's capacity to recover.

Furthermore, from the perspective of different parties such as employees, organizations, HRMs, and customers, conducting forward-looking theoretical discussions are required to provide service support for the hospitality industry to seize a new round of significant industry development opportunities to achieve leapfrog development. Additionally, regional and area hospitality HRM case studies can summarize actions and strategies that can be taken in times of disaster.

\section{Conclusions}

Given these efforts, the current study fulfilled the hospitality HRM field in several approaches. First, 102 publications were extracted with the specified keywords and analyzed with VOSview [46] and NVivo [15]. By assessing the current issue of COVID-19 and scientific knowledge of hospitality HRM, this study summarized the research state-of-art in this field. After reviewing to identify the top keywords, nodes, and seven themes, this study proposed a research agenda. Second, regarding to how factors and themes affect employee performance and service quality, this study proposes different interrelationships occurring at different progress of HR systems in predictable patterns by establishing a theoretical framework. From the perspective on the content of the theme dimension of hospitality HRM, antecedents such as environmental factors (e.g., COVID-19) and industry characteristics (e.g., particular sectors) affect the transformation of HRM practices. Through the progress, the antecedent factors have an impact on the organizational level (influence on organizations) and individual level (influence on the employee) performance through various HRM practices. Moreover, service, customers, and new techniques are transferred externally. HRM departments have the role in turning a crisis into an opportunity if only they can minimize the negative impact on employees and organizations by grasping the situation absolutely, responding and acting quickly, adjusting, and making the right decision.

In conclusion, the findings of this study shed light on the hospitality HRM research. Under the pandemic situation, the achievements of hospitality HRM research are fruitful. However, many areas are worthy of deliberation, such as HRM practice innovation and external outcomes (such as themes 6, service, customer, and technologies application). Combined with the environmental background and industrial characteristics, the new opportunities for the development of hospitality HRM in the post-pandemic era are more significant than the new challenges. That is, how HRM can navigate the hospitality in a 
complexity crisis context to achieve sustainable development and stable services output is the subject of research.

Nonetheless, certain limitations should be addressed. First, this study inevitably neglects to compare trends before and after the pandemic. For comparison, scholars usually labeled several phases for the pandemic [3] or mapped the timeline [10] for comparing the evolving. In order to overcome this limitation, it is proposed to increase collection time, add resources, and use mixed approaches to analyze the data. Second, this study is short on empirical data supporting. Therefore, the proposed research agenda should be carried out with a quantitative study. Additionally, future studies can be conducted precisely with other samples. This study utilized WoS databases, future study is encouraged to utilize multiple sample sets for a more comprehensive explanation.

Author Contributions: Conceptualization, J.W. and H.-S.K.; methodology, J.W.; analysis, J.W., H.-S.K. and H.-J.B.; writing—original draft preparation, J.W.; writing—review and editing, H.-W.J.; supervision, H.-S.K. All authors have read and agreed to the published version of the manuscript.

Funding: This research received no external funding.

Institutional Review Board Statement: Not applicable.

Informed Consent Statement: Not applicable.

Data Availability Statement: Data available in a publicly accessible repository.

Conflicts of Interest: The authors declare no conflict of interest.

\section{Appendix A}

Table A1. Sample list.

\begin{tabular}{|c|c|c|c|c|}
\hline & Authors & Y. & Title & Journal \\
\hline 1 & $\begin{array}{l}\text { Khawaja, Kausar Fiaz; Sarfraz, } \\
\text { Muddassar; Rashid, Misbah; } \\
\text { Rashid, Mariam }\end{array}$ & 2021 & $\begin{array}{l}\text { How is COVID-19 pandemic causing } \\
\text { employee withdrawal behavior in the } \\
\text { hospitality industry? An } \\
\text { empirical investigation }\end{array}$ & $\begin{array}{l}\text { Journal of Hospitality and } \\
\text { Tourism Insights }\end{array}$ \\
\hline 2 & $\begin{array}{l}\text { Park, Eunhye; Kim, } \\
\text { Woo-Hyuk; Kim, Sung-Bum }\end{array}$ & 2020 & $\begin{array}{l}\text { Tracking tourism and hospitality employees' } \\
\text { real-time perceptions and emotions in an } \\
\text { online community during the } \\
\text { COVID-19 pandemic }\end{array}$ & Current Issues in Tourism \\
\hline 3 & Tsui, Pei-Ling & 2021 & $\begin{array}{l}\text { Would organizational climate and job stress } \\
\text { affect wellness? An empirical study on the } \\
\text { hospitality industry in Taiwan } \\
\text { during COVID-19. }\end{array}$ & $\begin{array}{l}\text { International Journal of } \\
\text { Environmental Research and } \\
\text { Public Health }\end{array}$ \\
\hline 4 & $\begin{array}{l}\text { He, Jie; Mao, Yan; Morrison, } \\
\text { Alastair M.; Coca-Stefaniak, J. } \\
\text { Andres }\end{array}$ & 2021 & $\begin{array}{l}\text { On being warm and friendly: the effect of } \\
\text { socially responsible human resource } \\
\text { management on employee fears of the threats } \\
\text { of COVID-19 }\end{array}$ & $\begin{array}{l}\text { International Journal of } \\
\text { Contemporary Hospitality } \\
\text { Management }\end{array}$ \\
\hline 5 & $\begin{array}{l}\text { Bajrami, Dunja Demirovic; } \\
\text { Terzic, Aleksandra; Petrovic, } \\
\text { Marko D.; Radovanovic, Milan; } \\
\text { Tretiakova, Tatiana N.; } \\
\text { Hadoud, Abosa }\end{array}$ & 2021 & $\begin{array}{l}\text { Will we have the same employees in } \\
\text { hospitality after all? The impact of COVID-19 } \\
\text { on employees' work attitudes and } \\
\text { turnover intentions }\end{array}$ & $\begin{array}{l}\text { International Journal of } \\
\text { Hospitality Management }\end{array}$ \\
\hline 6 & $\begin{array}{l}\text { Tu, Yidong; Li, Diwan; Wang, } \\
\text { Hai-Jiang }\end{array}$ & 2021 & $\begin{array}{l}\text { COVID-19-induced layoff, survivors' } \\
\text { COVID-19-related stress and performance in } \\
\text { hospitality industry: The moderating role of } \\
\text { social support }\end{array}$ & $\begin{array}{l}\text { International Journal of } \\
\text { Hospitality Management }\end{array}$ \\
\hline
\end{tabular}


Table A1. Cont.

\begin{tabular}{|c|c|c|c|c|}
\hline & Authors & Y. & Title & Journal \\
\hline 7 & $\begin{array}{l}\text { Yan, Jiaqi; Kim, } \\
\text { Sunghoon; Zhang, } \\
\text { Stephen X.; Foo, } \\
\text { Maw-Der; } \\
\text { Alvarez-Risco, Aldo; } \\
\text { Del-Aguila-Arcentales, } \\
\text { Shyla; Yanez, Jaime A. }\end{array}$ & 2021 & $\begin{array}{l}\text { Hospitality workers' COVID-19 risk } \\
\text { perception and depression: A contingent } \\
\text { model based on transactional theory of } \\
\text { stress model }\end{array}$ & $\begin{array}{l}\text { International Journal of } \\
\text { Hospitality Management }\end{array}$ \\
\hline 8 & $\begin{array}{l}\text { Chadee, Doren; Ren, } \\
\text { Shuang; Tang, Guiyao }\end{array}$ & 2021 & $\begin{array}{l}\text { Is digital technology the magic bullet for } \\
\text { performing work at home? Lessons learned } \\
\text { for post COVID-19 recovery in } \\
\text { hospitality management }\end{array}$ & $\begin{array}{l}\text { International Journal of } \\
\text { Hospitality Management }\end{array}$ \\
\hline 9 & $\begin{array}{l}\text { Ruiz-Palomino, Pablo; } \\
\text { Yanez-Araque, Benito; } \\
\text { Jimenez-Estevez, Pedro; } \\
\text { Gutierrez-Broncano, } \\
\text { Santiago }\end{array}$ & 2022 & $\begin{array}{l}\text { Can servant leadership prevent hotel } \\
\text { employee depression during the COVID-19 } \\
\text { pandemic? A mediating and } \\
\text { multigroup analysis }\end{array}$ & $\begin{array}{l}\text { Technological Forecasting and } \\
\text { Social Change }\end{array}$ \\
\hline 10 & $\begin{array}{l}\text { Karatepe, Osman M.; } \\
\text { Saydam, Mehmet Bahri; } \\
\text { Okumus, Fevzi }\end{array}$ & 2021 & $\begin{array}{l}\text { COVID-19, mental health problems, and their } \\
\text { detrimental effects on hotel employees' } \\
\text { propensity to be late for work, absenteeism, } \\
\text { and life satisfaction }\end{array}$ & Current Issues in Tourism \\
\hline 11 & $\begin{array}{l}\text { Chen, Chun-Chu } \\
\text { (Bamboo); Chen, } \\
\text { Ming-Hsiang }\end{array}$ & 2021 & $\begin{array}{l}\text { Well-being and career change intention: } \\
\text { COVID-19's impact on unemployed and } \\
\text { furloughed hospitality workers }\end{array}$ & $\begin{array}{l}\text { International Journal of Contemporary } \\
\text { Hospitality Management }\end{array}$ \\
\hline 12 & $\begin{array}{l}\text { Mioch, Dymphie; } \\
\text { Kuiper, Sandra; van } \\
\text { den Bijllaardt, Wouter; } \\
\text { van Jaarsveld, Cornelia } \\
\text { H M; Kluytmans, Jan; } \\
\text { Lodder, Esther; } \\
\text { Wissing, Michel D }\end{array}$ & 2021 & $\begin{array}{l}\text { SARS-CoV-2 antibodies in employees } \\
\text { working in non-medical contact-intensive } \\
\text { professions in the Netherlands: Baseline data } \\
\text { from the prospective Co-study. }\end{array}$ & Preventive Medicine Reports \\
\hline 13 & $\begin{array}{l}\text { Rezapouraghdam, } \\
\text { Hamed; Karatepe, } \\
\text { Osman M. }\end{array}$ & 2020 & $\begin{array}{l}\text { Applying health belief model to unveil } \\
\text { employees' workplace COVID-19 protective } \\
\text { behaviors: insights for the } \\
\text { hospitality industry }\end{array}$ & $\begin{array}{l}\text { International Journal of Mental } \\
\text { Health Promotion }\end{array}$ \\
\hline 14 & $\begin{array}{l}\text { Altinay, Levent; Arici, } \\
\text { Hasan Evrim }\end{array}$ & 2021 & $\begin{array}{l}\text { Transformation of the hospitality services } \\
\text { marketing structure: a chaos } \\
\text { theory perspective }\end{array}$ & Journal of Services Marketing \\
\hline 15 & $\begin{array}{l}\text { Hu, Xiaowen; Yan, } \\
\text { Hongmin; Casey, } \\
\text { Tristan; Wu, Chia-Huei }\end{array}$ & 2021 & $\begin{array}{l}\text { Creating a safe haven during the crisis: How } \\
\text { organizations can achieve deep compliance } \\
\text { with COVID-19 safety measures in the } \\
\text { hospitality industry }\end{array}$ & $\begin{array}{l}\text { International Journal of } \\
\text { Hospitality Management }\end{array}$ \\
\hline 16 & $\begin{array}{l}\text { Qiu, Shangzhi } \\
\text { (Charles); Jiang, Jianing; } \\
\text { Liu, Xinming; Chen, } \\
\text { Ming-Hsiang; Yuan, } \\
\text { Xina }\end{array}$ & 2021 & $\begin{array}{l}\text { Can corporate social responsibility protect } \\
\text { firm value during the COVID-19 pandemic? }\end{array}$ & $\begin{array}{l}\text { International Journal of Hospitality } \\
\text { Management }\end{array}$ \\
\hline 17 & $\begin{array}{l}\text { Kang, Sung-Eun; Park, } \\
\text { Changyeon; Lee, } \\
\text { Choong-Ki; Lee, } \\
\text { Seunghoon }\end{array}$ & 2021 & $\begin{array}{l}\text { The stress-induced impact of COVID-19 on } \\
\text { tourism and hospitality workers }\end{array}$ & Sustainability \\
\hline 18 & $\begin{array}{l}\text { Chalupa, Stepan; } \\
\text { Chadt, Karel }\end{array}$ & 2021 & $\begin{array}{l}\text { The perception of soft skills and their training } \\
\text { at hotel front-office in connection to } \\
\text { COVID-19 pandemics }\end{array}$ & TEM Journal \\
\hline
\end{tabular}


Table A1. Cont.

\begin{tabular}{|c|c|c|c|c|}
\hline & Authors & Y. & Title & Journal \\
\hline 19 & $\begin{array}{l}\text { Im, Jinyoung; Kim, } \\
\text { Haemi; Miao, Li }\end{array}$ & 2021 & $\begin{array}{l}\text { CEO letters: Hospitality corporate narratives } \\
\text { during the COVID-19 pandemic }\end{array}$ & $\begin{array}{l}\text { International Journal of } \\
\text { Hospitality Management }\end{array}$ \\
\hline 20 & Agarwal, Promila & 2021 & $\begin{array}{l}\text { Shattered but smiling: Human resource } \\
\text { management and the wellbeing of hotel } \\
\text { employees during COVID-19 }\end{array}$ & $\begin{array}{l}\text { International Journal of } \\
\text { Hospitality Management }\end{array}$ \\
\hline
\end{tabular}

21 Park, In-Jo; Hai, Shenyang

2021

How does career future time perspective moderate in the relationship between infection anxiety with the COVID-19 and service behavior among hotel employees?
Tourism Management Perspectives

Vo-Thanh, Tan; Vu, Thinh-Van; Nguyen, Nguyen Phong;

22 Nguyen, Duy Van Zaman, Mustafeed; Chi,

How does hotel employees' satisfaction with Hsinkuang

23 Park, Chang-Yeon; Choong-Ki, Lee

The effects of the perceived stress and job anxiety of tourism industry employees on job satisfaction and life satisfaction in the context of COVID-19: Focusing on the moderating effect of government trust

Baum, Tom; Mooney, Shelagh K. K.;

24 Robinson, Richard N. S.; Solnet, David workforce-new crisis or amplification of the norm?
Korean Journal of Hospitality and Tourism

International Journal of Contemporary Hospitality Management
Journal of Sustainable Tourism the organization's COVID-19 responses affect job insecurity and job performance?
Diep Ngoc Su; Diep Luc Tra; Hanh My Thi

25 Huynh; Hai Hong Thi Nguyen; O'Mahony, Barry

Guzzo, Renata F.;

26 Wang, Xingyu; Madera, Juan M.; Abbott, JeAnna

27 Farooq, Rayees; Sultana, Almaas

Enhancing resilience in the Covid-19 crisis:

2021 lessons from human resource management practices in Vietnam

The potential impact of the COVID-19

\begin{tabular}{|c|c|}
\hline 28 & $\begin{array}{l}\text { Chi, Oscar Hengxuan; } \\
\text { Saldamli, Asim; }\end{array}$ \\
\hline
\end{tabular}

28 Saldamli, Asim; Gursoy, Dogan
Organizational trust in times of COVID-19:

2021 Hospitality employees' affective responses to managers' communication
International Journal of

Hospitality Management
Current Issues in Tourism

pandemic on work from home and employee Measuring Business Excellence productivity

Impact of the COVID-19 pandemic on

Burhan, Muhammad;

29 Salam, Muhammad

9 Talha; Abou Hamdan, Omar; Tariq, Hussain

30 Mensah, Christopher

2021

Shah, Chetan;

31 Chowdhury, Abhishek; Gupta, Vikas management-level hotel employees' work behaviors: Moderating effects of working-from-home

2021 Crisis management in the hospitality sector SMEs in Pakistan during COVID-19

International Journal of Hospitality Management

Using web-survey to collect data on psychological impacts of COVID-19 on hotel employees in Ghana: A methodological review

International Journal of Hospitality Management

Impact of COVID-19 on tourism and 2021 hospitality students' perceptions of career opportunities and future prospects in India

\section{Cogent Psychology}

Journal of Teaching in Travel and Tourism 
Table A1. Cont.

\begin{tabular}{|c|c|c|c|c|}
\hline & Authors & Y. & Title & Journal \\
\hline 32 & $\begin{array}{l}\text { Jung, Hyo Sun; Jung, } \\
\text { Yoon Sik; Yoon, Hye } \\
\text { Hyun }\end{array}$ & 2021 & $\begin{array}{l}\text { COVID-19: The effects of job insecurity on the } \\
\text { job engagement and turnover intent of deluxe } \\
\text { hotel employees and the moderating role of } \\
\text { generational characteristics }\end{array}$ & $\begin{array}{l}\text { International Journal of } \\
\text { Hospitality Management }\end{array}$ \\
\hline 33 & $\begin{array}{l}\text { Unguren, Engin; Tekin, } \\
\text { Omer Akgun; Avsalli, } \\
\text { Huseyin; Kacmaz, } \\
\text { Yasar Yigit }\end{array}$ & 2021 & $\begin{array}{l}\text { The Moderator Role of Financial Well-Being } \\
\text { on the Effect of Job Insecurity and the } \\
\text { COVID-19 Anxiety on Burnout: A Research } \\
\text { on Hotel-Sector Employees in Crisis }\end{array}$ & Sustainability \\
\hline 34 & $\begin{array}{l}\text { Aguiar-Quintana, } \\
\text { Teresa; Nguyen, Thi } \\
\text { Hong Hai; } \\
\text { Araujo-Cabrera, } \\
\text { Yasmina; } \\
\text { Sanabria-Diaz, Jose M. }\end{array}$ & 2021 & $\begin{array}{l}\text { Do job insecurity, anxiety and depression } \\
\text { caused by the COVID- } 19 \text { pandemic influence } \\
\text { hotel employees' self-rated task performance? } \\
\text { The moderating role of employee resilience }\end{array}$ & $\begin{array}{l}\text { International Journal of } \\
\text { Hospitality Management }\end{array}$ \\
\hline 35 & Luu Trong Tuan & 2021 & $\begin{array}{l}\text { Employer event communication and } \\
\text { hospitality workers' resilience during the } \\
\text { COVID-19 crisis: the role of core beliefs } \\
\text { examination and family support }\end{array}$ & $\begin{array}{l}\text { International Journal of Contemporary } \\
\text { Hospitality Management }\end{array}$ \\
\hline 36 & $\begin{array}{l}\text { Wang, Yao-Chin; Chi, } \\
\text { Christina Geng-Qing; } \\
\text { Erkilic, Eren }\end{array}$ & 2021 & $\begin{array}{l}\text { The impact of religiosity on political skill: } \\
\text { evidence from Muslim hotel employees } \\
\text { in Turkey }\end{array}$ & $\begin{array}{l}\text { International Journal of Contemporary } \\
\text { Hospitality Management }\end{array}$ \\
\hline 37 & $\begin{array}{l}\text { Filimonau, Viachaslau; } \\
\text { Derqui, Belen; } \\
\text { Matute, Jorge }\end{array}$ & 2020 & $\begin{array}{l}\text { The COVID- } 19 \text { pandemic and organizational } \\
\text { commitment of senior hotel managers }\end{array}$ & $\begin{array}{l}\text { International Journal of } \\
\text { Hospitality Management }\end{array}$ \\
\hline 38 & $\begin{array}{l}\text { Choi, Miju; } \\
\text { Choi, Youngjoon }\end{array}$ & 2021 & $\begin{array}{l}\text { Employee perceptions of hotel CSR activities } \\
\text { during the COVID-19 pandemic }\end{array}$ & $\begin{array}{l}\text { International Journal of Contemporary } \\
\text { Hospitality Management }\end{array}$ \\
\hline 39 & $\begin{array}{l}\text { Khatri, Puja; Raina, } \\
\text { Khushboo; Dutta, } \\
\text { Sumedha; Pahwa, } \\
\text { Harshleen; } \\
\text { Kumari, Preeti }\end{array}$ & 2021 & $\begin{array}{l}\text { Reaction to COVID-19, social media } \\
\text { engagement and well-being: a } \\
\text { mediation analysis }\end{array}$ & $\begin{array}{l}\text { A Journal of The Social and Economic } \\
\text { Relations of Work }\end{array}$ \\
\hline 40 & $\begin{array}{l}\text { Seyitoglu, Faruk; } \\
\text { Ivanov, Stanislav }\end{array}$ & 2021 & $\begin{array}{l}\text { Service robots as a tool for physical distancing } \\
\text { in tourism }\end{array}$ & Current Issues in Tourism \\
\hline 41 & Lin, Fang-Yi & 2021 & $\begin{array}{l}\text { Effectiveness of the talent cultivation training } \\
\text { program for industry transformation in } \\
\text { Taiwan during the COVID-19 pandemic }\end{array}$ & Service Business \\
\hline 42 & $\begin{array}{l}\text { Manoharan, } \\
\text { Ashokkumar; Jones, } \\
\text { Janice; Jiang, Zhou; } \\
\text { Singal, Manisha }\end{array}$ & 2021 & $\begin{array}{l}\text { Career optimism of culturally and } \\
\text { linguistically diverse hotel workers in the } \\
\text { pandemic age }\end{array}$ & $\begin{array}{l}\text { International Journal of Hospitality } \\
\text { Management }\end{array}$ \\
\hline 43 & $\begin{array}{l}\text { Canhoto, Ana Isabel; } \\
\text { Wei, Liyuan }\end{array}$ & 2021 & $\begin{array}{l}\text { Stakeholders of the world, unite!: Hospitality } \\
\text { in the time of COVID-19 }\end{array}$ & $\begin{array}{l}\text { International Journal of } \\
\text { Hospitality Management }\end{array}$ \\
\hline 44 & $\begin{array}{l}\text { Kaushal, Vikrant; } \\
\text { Srivastava, Sidharth }\end{array}$ & 2021 & $\begin{array}{l}\text { Hospitality and tourism industry amid } \\
\text { COVID-19 pandemic: Perspectives on } \\
\text { challenges and learnings from India }\end{array}$ & $\begin{array}{l}\text { International Journal of } \\
\text { Hospitality Management }\end{array}$ \\
\hline
\end{tabular}

Bozovic, Tamara; Blesic,

Ivana; Knezevic

45 Milena Nedeljkovic; Deri, Lukrecija; Pivac, Tatjana

Zhang, Jiangchi; Xie,

46 Chaowu; Morrison, Alastair M.
Resilience of tourism employees to changes caused by COVID-19 pandemic
Journal of The Geographical Institute
The effect of corporate social responsibility on hotel employee safety behavior during COVID-19: The moderation of belief restoration and negative emotions
Journal of Hospitality and Tourism Management 
Table A1. Cont.

\begin{tabular}{|c|c|c|c|c|}
\hline & Authors & Y. & Title & Journal \\
\hline 47 & $\begin{array}{l}\text { Singh, Nidhi; Bhatia, } \\
\text { Shikha; Nigam, } \\
\text { Shailendra }\end{array}$ & 2021 & $\begin{array}{l}\text { Perceived vulnerability of job loss and } \\
\text { satisfaction with life in the hospitality sector } \\
\text { in times of pandemic: a } \\
\text { multi-mediational approach }\end{array}$ & $\begin{array}{l}\text { International Journal of Contemporary } \\
\text { Hospitality Management }\end{array}$ \\
\hline 48 & $\begin{array}{l}\text { Wu, Gang; Liang, } \\
\text { Lifang; Gursoy, Dogan }\end{array}$ & 2021 & $\begin{array}{l}\text { Effects of the new COVID-19 normal on } \\
\text { customer satisfaction: Can facemasks level off } \\
\text { the playing field between average-looking } \\
\text { and attractive-looking employees? }\end{array}$ & $\begin{array}{l}\text { International Journal of } \\
\text { Hospitality Management }\end{array}$ \\
\hline 49 & $\begin{array}{l}\text { Lee, Patrick C.; Xu, Shi } \\
\text { (Tracy); Yang, Wan }\end{array}$ & 2021 & $\begin{array}{l}\text { Is career adaptability a double-edged sword? } \\
\text { The impact of work social support and career } \\
\text { adaptability on turnover intentions during } \\
\text { the COVID-19 pandemic }\end{array}$ & $\begin{array}{l}\text { International Journal of } \\
\text { Hospitality Management }\end{array}$ \\
\hline 50 & $\begin{array}{l}\text { Bichler, Bernhard } \\
\text { Fabian; Petry, Tanja; } \\
\text { Peters, Mike }\end{array}$ & 2021 & $\begin{array}{l}\text { 'We did everything we could': how } \\
\text { employees' made sense of COVID-19 in the } \\
\text { tourism and hospitality industry }\end{array}$ & Current Issues in Tourism \\
\hline 51 & Chen, I-Shuo & 2020 & $\begin{array}{l}\text { Turning home boredom during the outbreak } \\
\text { of COVID-19 into thriving at home and career } \\
\text { self-management: the role of online leisure } \\
\text { crafting }\end{array}$ & $\begin{array}{l}\text { International Journal of Hospitality } \\
\text { Management }\end{array}$ \\
\hline 52 & $\begin{array}{l}\text { Zhang, Jiangchi; Xie, } \\
\text { Chaowu; Wang, } \\
\text { Jianying; Morrison, } \\
\text { Alastair M.; } \\
\text { Coca-Stefaniak, J. } \\
\text { Andres }\end{array}$ & 2020 & $\begin{array}{l}\text { Responding to a major global crisis: the } \\
\text { effects of hotel safety leadership on employee } \\
\text { safety behavior during COVID-19 }\end{array}$ & $\begin{array}{l}\text { International Journal of } \\
\text { Hospitality Management }\end{array}$ \\
\hline 53 & $\begin{array}{l}\text { Teng, Yi-Man; Wu, } \\
\text { Kun-Shan; Lin, } \\
\text { Kuan-Ling; Xu, Dan }\end{array}$ & 2020 & $\begin{array}{l}\text { Mental health impact of COVID-19 on } \\
\text { quarantine hotel employees in China }\end{array}$ & Risk Management and Healthcare Policy \\
\hline 54 & $\begin{array}{l}\text { Kim, Seontaik; Kim, } \\
\text { Peter Beomcheol; } \\
\text { Lee, Gyumin }\end{array}$ & 2021 & $\begin{array}{l}\text { Predicting hospitality employees' safety } \\
\text { performance behaviors in the COVID-19 } \\
\text { pandemic }\end{array}$ & $\begin{array}{l}\text { International Journal of } \\
\text { Hospitality Management }\end{array}$ \\
\hline 55 & $\begin{array}{l}\text { Gurlek, Mert; } \\
\text { Kilic, Ilker }\end{array}$ & 2021 & $\begin{array}{l}\text { A true friend becomes apparent on a rainy } \\
\text { day: Corporate social responsibility practices } \\
\text { of top hotels during the COVID-19 pandemic }\end{array}$ & Current Issues in Tourism \\
\hline 56 & Farrer, James & 2020 & $\begin{array}{l}\text { How are Tokyo's independent restauranteurs } \\
\text { surviving the pandemic? }\end{array}$ & Asia-Pacific Journal-Japan Focus \\
\hline 57 & $\begin{array}{l}\text { Song, Hanqun; Ma, } \\
\text { Emily; Cheng, } \\
\text { Mingming }\end{array}$ & 2021 & $\begin{array}{l}\text { Dining with distance during the pandemic: } \\
\text { an enquiry from the theory of proxemics and } \\
\text { social exchange }\end{array}$ & Current Issues in Tourism \\
\hline
\end{tabular}

Yuan, Yue; Kong, Haiyan; Baum, Tom;

58 Liu, Yining; Liu, Chao; $\mathrm{Bu}$, Naipeng; Wang, Kangping; Yin, Zihan Yu, Heyao; Lee,

59 Lindsey; Popa, Iuliana; 2021 Madera, Juan M.
Transformational leadership and trust in leadership impacts on employee commitment
Tourism Review

Should I leave this industry? The role of stress and negative emotions in response to an industry negative work event

COVID-19 and unpaid leave: Impacts of psychological contract breach on organizational distrust and turnover intention: Mediating role of
International Journal of

Hospitality Management
Abdalla, Moh'd Juma;

60 Laiba; Ali, Faizan; Chen, Xianglan emotional exhaustion 
Table A1. Cont.

\begin{tabular}{|c|c|c|c|c|}
\hline & Authors & Y. & Title & Journal \\
\hline 61 & $\begin{array}{l}\text { Zhong, Yifan; Li, } \\
\text { Yameng; Ding, Jian; } \\
\text { Liao, Yiyi }\end{array}$ & 2021 & $\begin{array}{l}\text { Risk Management: Exploring emerging } \\
\text { human resource issues during the } \\
\text { COVID-19 pandemic }\end{array}$ & $\begin{array}{l}\text { Journal of Risk and } \\
\text { Financial Management }\end{array}$ \\
\hline 62 & $\begin{array}{l}\text { Bhrammanachote, } \\
\text { Winayaporn; } \\
\text { Sawangdee, Yothin }\end{array}$ & 2021 & $\begin{array}{l}\text { Sustaining or surviving? An exploratory case } \\
\text { study on COVID-19's impact towards hotel } \\
\text { businesses }\end{array}$ & Tourism and Hospitality Management \\
\hline 63 & $\begin{array}{l}\text { Salem, Islam } \\
\text { Elbayoumi; Elbaz, } \\
\text { Ahmed Mohamed; } \\
\text { Elkhwesky, Zakaria; } \\
\text { Ghazi, Karam Mansour }\end{array}$ & 2021 & $\begin{array}{l}\text { The COVID-19 pandemic: The mitigating role } \\
\text { of government and hotel support of hotel } \\
\text { employees in Egypt }\end{array}$ & Tourism Management \\
\hline 64 & Yu, Yang & 2021 & $\begin{array}{l}\text { Situation of hotels in henan under the } \\
\text { influence of COVID-19 epidemic prevention } \\
\text { and control }\end{array}$ & $\begin{array}{l}\text { Basic and Clinical Pharmacology } \\
\text { and Toxicology }\end{array}$ \\
\hline 65 & $\begin{array}{l}\text { Murray, William C.; } \\
\text { Holmes, Mark R. }\end{array}$ & 2021 & $\begin{array}{l}\text { Impacts of employee empowerment and } \\
\text { organizational commitment on } \\
\text { workforce sustainability }\end{array}$ & Sustainability \\
\hline 66 & $\begin{array}{l}\text { Yacoub, Laurent; } \\
\text { ElHajjar, Samer }\end{array}$ & 2021 & $\begin{array}{l}\text { How do hotels in developing countries } \\
\text { manage the impact of COVID-19? The case of } \\
\text { Lebanese hotels }\end{array}$ & $\begin{array}{l}\text { International Journal of Contemporary } \\
\text { Hospitality Management }\end{array}$ \\
\hline 67 & $\begin{array}{l}\text { Salem, Islam } \\
\text { Elbayoumi; Elkhwesky, } \\
\text { Zakaria; Ramkissoon, } \\
\text { Haywantee }\end{array}$ & 2021 & $\begin{array}{l}\text { A content analysis for governments and } \\
\text { hotels' response to COVID-19 pandemic } \\
\text { in Egypt }\end{array}$ & Tourism and Hospitality Research \\
\hline 68 & $\begin{array}{l}\text { Goh, Edmund; } \\
\text { Baum, Tom }\end{array}$ & 2021 & $\begin{array}{l}\text { Job perceptions of Generation Z hotel } \\
\text { employees towards working in Covid-19 } \\
\text { quarantine hotels: the role of } \\
\text { meaningful work }\end{array}$ & $\begin{array}{l}\text { International Journal of Contemporary } \\
\text { Hospitality Management }\end{array}$ \\
\hline
\end{tabular}

Mejia, Cynthia;

Pittman, Rebecca;

69 Beltramo, Jenna M. D.;

69 Horan, Kristin; Grinley,

Amanda;

Shoss, Mindy K.

Abbas, Muhammad;

70 Malik, Mehwish;

Sarwat, Nosheen out-group perceptions of essential service workers during COVID-19

International Journal of

Hospitality Management

Consequences of job insecurity for hospitality

2021 workers amid COVID-19 pandemic: does social support help?

71 Kaygin, Erdogan; Topcuoglu, Ethem

The effects of COVID-19 pandemic upon tourism: A sample from the city of Kars

Brizek, Michael G.;

72 Frash, Robert E.;

McLeod, Brumby M.;

Patience, Melinda O.

Independent restaurant operator perspectives in the wake of the COVID-19 pandemic
Journal of Hospitality Marketing and Management

Journal of Mehmet Akif Ersoy University Economics and Administrative Sciences Faculty

International Journal of Hospitality Management
Rawal, Yashwant Singh;

73 Pal, Sanjeeb; Bagchi, Purnendu;

Dani, Rakesh

74 Kearney, N; Hambly, R; Alsharqi, A; Kirby, B

Hygiene and safety: A review of the hotel industry in the era of COVID-19 pandemic

Not relevant responses in the era of

2021 COVID-19-are we underestimating dermatology life quality index values?

75 Gupta, Vikas; Sahu, Garima
Reviving the Indian hospitality industry after the COVID-19 pandemic: the role of innovation in training
Bioscience Biotechnology

Research Communications

The British Journal of Dermatology

Worldwide Hospitality and

Tourism Themes 
Table A1. Cont.

\begin{tabular}{|c|c|c|c|c|}
\hline & Authors & Y. & Title & Journal \\
\hline 76 & $\begin{array}{l}\text { Yorulmaz, Murat; } \\
\text { Sevinc, Figen }\end{array}$ & 2021 & $\begin{array}{l}\text { Supervisor support and turnover intentions } \\
\text { of yacht captains: the role of work-family } \\
\text { conflict and psychological resilience during } \\
\text { the COVID-19 pandemic }\end{array}$ & $\begin{array}{l}\text { International Journal of Contemporary } \\
\text { Hospitality Management }\end{array}$ \\
\hline 77 & $\begin{array}{l}\text { Robinson, Richard N. } \\
\text { S.; Brenner, Matthew L. }\end{array}$ & 2021 & $\begin{array}{l}\text { Wage theft in professional kitchens: Conned } \\
\text { or complicit? }\end{array}$ & Hospitality and Society \\
\hline 78 & $\begin{array}{l}\text { Rosemberg, } \\
\text { Marie-Anne S.; Adams, } \\
\text { Mackenzie; Polick, } \\
\text { Carri; Li, Wei V.; Dang, } \\
\text { Jenny; Tsai, Jenny } \\
\text { Hsin-Chun }\end{array}$ & 2021 & $\begin{array}{l}\text { COVID-19 and mental health of food retail, } \\
\text { food service, and hospitality workers }\end{array}$ & $\begin{array}{l}\text { Journal of Occupational and } \\
\text { Environmental Hygiene }\end{array}$ \\
\hline
\end{tabular}

Robina-Ramirez,

Rafael;

Medina-Merodio,

79 Jose-Amelio;

Moreno-Luna, Libertad;

Safety and health measures for COVID-19 transition period in the hotel industry in Spain

International Journal of Environmental Research and Public Health

Jimenez-Naranjo,

Hector V.; Sanchez-Oro Marcelo

Grandey, Alicia A.;

80 Sayre, Gordon M.; French, Kimberly A.

A blessing and a curse: Work loss during coronavirus lockdown on short-term health changes via threat and recovery

ournal of Occupational

Health Psychology

Ramkissoon,

81 Haywantee; Mavondo,

Felix; Sowamber,

Corporate social responsibility at LUX*

resorts and hotels: satisfaction and loyalty

implications for employee and customer social responsibility

Vishnee

impact of psychological capital and life

82 Pathak, Deepti; Joshi, Gaurav

2021 satisfaction on organizational resilience during COVID-19: Indian tourism insights

Li, Minglong; Yin,

83 Dexiang; Qiu, Hailian;

2021

Bai, Billy

A systematic review of AI technology-based

service encounters: Implications for

hospitality and tourism operations

Using social media to preserve consumers'

84 Fuste-Forne, Francesc; Filimon, Nela awareness on food identity in times of crisis: The case of bakeries

85 Haarmeyer, David

Private equity and the COVID-19 economic downturn: Opportunity for expansion?

Responding to organizational identity change: ethnographic insights from multinational hotel subsidiaries

86 Ponting, Sandra Sun-Ah

Job turnover and the policy response in the

87 Acheson, Jean

2021
Sustainability

Current Issues in Tourism

International Journal of Hospitality

Management

International Journal of Environmental

Research and Public Health

Journal of Applied Corporate Finance

Journal of Hospitality and

Tourism Technology

Economic and Social Review

Fitzgerald, Niamh; Uny, Isabelle; Brown, Ashley;

88 Eadie, Douglas; Ford, Allison; Lewsey, Jim; COVID-19 era

Managing COVID-19 transmission risks in Bars: An interview and observation study
Journal of Studies on Alcohol and Drugs Stead, Martine

Sharma, Abhinav; Shin,

89 Hakseung; Jesus Santa-Maria, Maria; Luis Nicolau, Juan

90 Boccia, Mark; Cseh, 90 Maria
Hotels' COVID-19 innovation and performance

Annals of Tourism Research

Full-service restaurants as learning organizations: a multiple-site case study
Learning Organization 
Table A1. Cont.

\begin{tabular}{llll}
\hline Authors & Y. & Title & Journal \\
\hline $\begin{array}{l}\text { Ferreira, Sandra; } \\
\begin{array}{l}\text { Pereira, Olga; Simoes, } \\
\text { Claudia }\end{array}\end{array}$ & 2021 & $\begin{array}{l}\text { Environmental sustainability in the hotel } \\
\text { industry: A perspective from eco hotel } \\
\text { managers in Portugal }\end{array}$ & $\begin{array}{l}\text { International Journal of Marketing } \\
\text { Communication and New Media }\end{array}$ \\
\hline
\end{tabular}

92 Hong, Semyung

2021

93 Williams, Colin C. Kayaoglu, Aysegul

de Vries, Klaas;

94 Erumban, Abdul; van Ark, Bart

95

Hyoseon, Park; Hany, Kim

The effect of job image and occupational values on the employment preparation Behavior among university students with majors related to aviation tourism

COVID-19 and undeclared work: impacts and policy responses in Europe

Productivity and the pandemic: short-term disruptions and long-term implications: The impact of the COVID-19 pandemic on productivity dynamics by industry

The relationship between job insecurity and pro-social service behavior of LCC flight attendants, and the effect of job stress and $A B$ personality type

Qualitative evidence on the relationships

96 Irvine, Annie Louise

between precarious employment and mental health in western economies: a scoping review protocol

Mao, Yan; He, Jie;

97

Morrison, Alastair M.;

Coca-Stefaniak, J.

2021

Effects of tourism CSR on employee psychological capital in the COVID-19 crisis: from the perspective of conservation of resources theory

Andres

98 Aigbedo, Henry Impact of COVID-19 on the hospitality industry: A supply chain resilience perspective

The role of business model innovation in the

Breier, Matthias; Kallmuenzer, Andreas;

99 Clauss, Thomas; Gast, Johanna; Kraus, Sascha; Tiberius, Victor

Yu, Jongsik; Seo,

100 Jungwoon; Hyun, Sunghyup Sean

101 Jiang, Yangyang; Wen, Jun

\section{1 hospitality industry during the} COVID-19 crisis

International Journal of

Hospitality Management

Korean Journal of Hospitality

and Tourism

Open Science Framework

Current Issues in Tourism

International Journal of

Hospitality Management

Perceived hygiene attributes in the hotel

2021 industry: customer retention amid the COVID-19 crisis

International Journal of

Hospitality Management

Effects of COVID-19 on hotel marketing and management: a perspective article

International Journal of Contemporary Hospitality Management

Physical proximity, corporate social responsibility, and the impact of negative investor sentiment on stock returns: Evidence

International Review of Finance
102 Mingsheng; Chan, Kam 2020 C.; Liu, Qingzhuo

\section{Appendix B}

Table A2. Top 100 words.

\begin{tabular}{llllll}
\hline & Word & Length & Count & Weighted Percentage & Similar Words \\
\hline 1 & employees & 9 & 433 & $2.02 \%$ & employee, employees, employees' \\
\hline 2 & covid & 5 & 310 & $1.44 \%$ & 'covid, covid \\
\hline 3 & hotels & 6 & 239 & $1.11 \%$ & hotel, hotels, hotels' \\
\hline
\end{tabular}


Table A2. Cont.

\begin{tabular}{|c|c|c|c|c|c|}
\hline & Word & Length & Count & Weighted Percentage & Similar Words \\
\hline 4 & hospitality & 11 & 235 & $1.09 \%$ & hospitality, hospitals \\
\hline 5 & working & 7 & 207 & $0.96 \%$ & work, worked, working, works \\
\hline 6 & pandemic & 8 & 193 & $0.90 \%$ & pandemic, pandemics \\
\hline 7 & managers & 8 & 179 & $0.83 \%$ & $\begin{array}{l}\text { manage, manageable, managed, management, manager, } \\
\text { managers, managers', managing }\end{array}$ \\
\hline 8 & effects & 7 & 172 & $0.80 \%$ & effect, effective, effectively, effectiveness, effects \\
\hline 9 & job & 3 & 170 & $0.79 \%$ & job, jobs \\
\hline 10 & industry & 8 & 164 & $0.76 \%$ & industrial, industries, industry \\
\hline 11 & social & 6 & 136 & $0.63 \%$ & social, socially \\
\hline 12 & health & 6 & 134 & $0.62 \%$ & health \\
\hline 13 & impact & 6 & 121 & $0.56 \%$ & impact, impacted, impactful, impacting, impacts \\
\hline 14 & employed & 8 & 120 & $0.56 \%$ & employed, employer, employers, employing, employment \\
\hline 15 & practices & 9 & 118 & $0.55 \%$ & practical, practically, practice, practices \\
\hline 16 & role & 4 & 115 & $0.54 \%$ & role, roles \\
\hline 17 & organizational & 14 & 108 & $0.50 \%$ & organizational \\
\hline 18 & crisis & 6 & 93 & $0.43 \%$ & crisis \\
\hline 19 & tourism & 7 & 88 & $0.41 \%$ & tourism \\
\hline 20 & support & 7 & 88 & $0.41 \%$ & support, supported, supportive, supports \\
\hline 21 & relationship & 12 & 87 & $0.41 \%$ & relationship, relationships \\
\hline 22 & behavior & 8 & 80 & $0.37 \%$ & behavior, behavioral, behaviors \\
\hline 23 & examining & 9 & 79 & $0.37 \%$ & examination, examine, examined, examines, examining \\
\hline 24 & mental & 6 & 78 & $0.36 \%$ & mental \\
\hline 25 & precariousness & 14 & 74 & $0.34 \%$ & precari, precarious, precariously, precariousness \\
\hline 26 & well & 4 & 74 & $0.34 \%$ & well, wellness \\
\hline 27 & service & 7 & 74 & $0.34 \%$ & service, services, servicing \\
\hline 28 & positively & 10 & 74 & $0.34 \%$ & $\begin{array}{l}\text { posited, position, positionality, positions, positive, } \\
\text { positively, posits }\end{array}$ \\
\hline 29 & responsibility & 14 & 74 & $0.34 \%$ & response, responses, responsibility, responsible \\
\hline 30 & model & 5 & 73 & $0.34 \%$ & model, modeling, modelling, models \\
\hline 31 & relations & 9 & 73 & $0.34 \%$ & $\begin{array}{l}\text { relate, related, relates, relating, relation, relational, } \\
\text { relations, relative, relatively }\end{array}$ \\
\hline 32 & negative & 8 & 71 & $0.33 \%$ & negative, negatively, negatives, negativities \\
\hline 33 & data & 4 & 70 & $0.33 \%$ & data \\
\hline 34 & influence & 9 & 69 & $0.32 \%$ & influence, influenced, influences, influencing \\
\hline 35 & moderation & 10 & 68 & $0.32 \%$ & $\begin{array}{l}\text { moderate, moderated, moderates, moderating, } \\
\text { moderation, moderator }\end{array}$ \\
\hline 36 & review & 6 & 67 & $0.31 \%$ & review, reviewed, reviewer, reviews \\
\hline 37 & satisfaction & 12 & 67 & $0.31 \%$ & satisfaction \\
\hline 38 & $\operatorname{csr}$ & 3 & 66 & $0.31 \%$ & $\operatorname{csr}$ \\
\hline 39 & workers' & 8 & 66 & $0.31 \%$ & worker, workers, workers' \\
\hline 40 & mediators & 9 & 65 & $0.30 \%$ & $\begin{array}{l}\text { mediate, mediated, mediates, mediating, mediation, } \\
\text { mediational, mediator, mediators }\end{array}$ \\
\hline 41 & analysis & 8 & 64 & $0.30 \%$ & analysis \\
\hline
\end{tabular}


Table A2. Cont.

\begin{tabular}{|c|c|c|c|c|}
\hline Word & Length & Count & Weighted Percentage & Similar Words \\
\hline 42 implications & 12 & 64 & $0.30 \%$ & implications \\
\hline 43 customer & 8 & 64 & $0.30 \%$ & customer, customers, customers', customized \\
\hline 44 approaches & 10 & 63 & $0.29 \%$ & approach, approaches \\
\hline 45 affect & 6 & 63 & $0.29 \%$ & affect, affected, affecting, affective, affects \\
\hline 46 psychological & 13 & 62 & $0.29 \%$ & psychological, psychologically, psychology \\
\hline 47 provide & 7 & 62 & $0.29 \%$ & provide, provided, provides, providing \\
\hline 48 intentions & 10 & 61 & $0.28 \%$ & intent, intention, intentions \\
\hline 49 resilience & 10 & 61 & $0.28 \%$ & resilience, resiliency, resilient \\
\hline 50 significantly & 13 & 60 & $0.28 \%$ & significance, significant, significantly \\
\hline 51 organization & 12 & 60 & $0.28 \%$ & organization, organizations, organized, organizing \\
\hline 52 perceived & 9 & 60 & $0.28 \%$ & perceive, perceived \\
\hline 53 career & 6 & 59 & $0.27 \%$ & career, careers, careers' \\
\hline 54 shows & 5 & 58 & $0.27 \%$ & show, showed, showing, shows \\
\hline 55 insecurity & 10 & 57 & $0.27 \%$ & insecure, insecurity \\
\hline 56 safety & 6 & 57 & $0.27 \%$ & safety \\
\hline 57 times & 5 & 57 & $0.27 \%$ & time, timely, times \\
\hline 58 levels & 6 & 57 & $0.27 \%$ & level, levels \\
\hline 59 stress & 6 & 57 & $0.27 \%$ & stress, stress', stressful, stressing \\
\hline 60 home & 4 & 56 & $0.26 \%$ & home \\
\hline 61 factors & 7 & 54 & $0.25 \%$ & factor, factors \\
\hline 62 performed & 9 & 54 & $0.25 \%$ & $\begin{array}{l}\text { perform, performance, performances, performed, } \\
\text { performing }\end{array}$ \\
\hline 63 develops & 8 & 53 & $0.25 \%$ & develop, developed, developing, development, develops \\
\hline 64 based & 5 & 52 & $0.24 \%$ & base, based \\
\hline 65 purposive & 9 & 52 & $0.24 \%$ & purpose, purposes, purposive, purposively \\
\hline 66 survey & 6 & 50 & $0.23 \%$ & survey, surveyed, surveying, surveys \\
\hline 67 change & 6 & 50 & $0.23 \%$ & change, changed, changes, changing \\
\hline 68 risk & 4 & 50 & $0.23 \%$ & risk, risks \\
\hline 69 theory & 6 & 50 & $0.23 \%$ & theories, theory \\
\hline 70 perceptions & 11 & 49 & $0.23 \%$ & perception, perceptions \\
\hline 71 trust & 5 & 47 & $0.22 \%$ & trust \\
\hline 72 turnover & 8 & 47 & $0.22 \%$ & turnover \\
\hline 73 resource & 8 & 47 & $0.22 \%$ & resource, resources \\
\hline 74 structural & 10 & 47 & $0.22 \%$ & structural, structure, structured, structures \\
\hline 75 business & 8 & 46 & $0.21 \%$ & business, businesses, businesses' \\
\hline 76 sector & 6 & 46 & $0.21 \%$ & sector, sectoral, sectors \\
\hline 77 need & 4 & 46 & $0.21 \%$ & need, needed, needs \\
\hline 78 including & 9 & 45 & $0.21 \%$ & include, included, includes, including \\
\hline 79 self & 4 & 44 & $0.20 \%$ & self \\
\hline 80 aims & 4 & 44 & $0.20 \%$ & aim, aimed, aims \\
\hline 81 methodology & 11 & 44 & $0.20 \%$ & methodological, methodology \\
\hline 82 design & 6 & 44 & $0.20 \%$ & design, designed \\
\hline 83 experiment & 10 & 43 & $0.20 \%$ & experience, experiences, experiment \\
\hline
\end{tabular}


Table A2. Cont.

\begin{tabular}{|c|c|c|c|c|}
\hline Word & Length & Count & Weighted Percentage & Similar Words \\
\hline 84 theoretical & 11 & 40 & $0.19 \%$ & theoretical, theoretically \\
\hline 85 knowledge & 9 & 40 & $0.19 \%$ & knowledge, knowledgeable \\
\hline 86 discussion & 10 & 40 & $0.19 \%$ & discuss, discussed, discusses, discussion \\
\hline 872020 & 4 & 40 & $0.19 \%$ & 2020 \\
\hline 88 online & 6 & 38 & $0.18 \%$ & online \\
\hline 89 future & 6 & 38 & $0.18 \%$ & future, futures \\
\hline 90 new & 3 & 38 & $0.18 \%$ & 'new, new \\
\hline 91 human & 5 & 37 & 0.0017 & human, humanized \\
\hline 92 addition & 8 & 37 & 0.0017 & addition, additional, additionally \\
\hline 93 contributes & 11 & 37 & 0.0017 & $\begin{array}{l}\text { contribute, contributed, contributes, contributing, } \\
\text { contribution, contributions }\end{array}$ \\
\hline 94 values & 6 & 37 & 0.0017 & value, values \\
\hline 95 commitment & 10 & 37 & 0.0017 & commitment, commitments, committed \\
\hline 96 family & 6 & 36 & 0.0017 & families, families', family \\
\hline 97 emotional & 9 & 36 & 0.0017 & emotional, emotions \\
\hline 98 marketing & 9 & 36 & 0.0017 & market, marketers, marketing, markets \\
\hline 99 group & 5 & 36 & 0.0017 & group, groups \\
\hline 100 qualitative & 11 & 35 & 0.0016 & qualitative \\
\hline
\end{tabular}

\section{References}

1. Nicole, M.; Alsafi, Z.; Sohrabi, C.; Kerwan, A.; Al-Jabir, A.; Losifidis, C.; Agha, M.; Agha, R. The socio-economic implications of the coronavirus and COVID-19 pandemic: A review. Int. J. Surg. 2020, 78, 185-193. [CrossRef] [PubMed]

2. McIntosh, R.W.; Goeldner, C.R.; Ritchie, J.B. Tourism in perspective. In Tourism: Principles, Practices, Philosophies, 7nd ed.; John Wiley and Sons: Hoboken, NJ, USA, 2007; pp. 3-35.

3. Hao, F.; Xiao, Q.; Chon, K. COVID-19 and China's hotel industry: Impacts, a disaster management framework, and post-pandemic agenda. Int. J. Hosp. Manag. 2020, 90, 102636. [CrossRef] [PubMed]

4. Kim, Y.; Kim, H.; Kim, H. Understanding the effects of COVID-19 on the Starbucks perception through big data analytics: A comparative study. Culin. Sci. Hosp. Res. 2021, 27, 1-14. [CrossRef]

5. Mun, J.; Ban, H.; Kim, H. A study on consumers' perception of meal-kit: After the spread of coronavirus infectious disease-19 (COVID-19). Culin. Sci. Hosp. Res. 2020, 26, 198-207.

6. $\quad$ Fitzgerald, N.; Uny, I.; Brown, A.; Eadie, D.; Ford, A.; Lewsey, J.; Stead, M. Managing COVID-19 transmission risks in bars: An interview and observation study. J. Stud. Alcohol Drugs Suppl. 2021, 82, 42-54. [CrossRef]

7. Alonso, A.D.; Kok, S.K.; Bressan, A.; O'Shea, M.; Sakellarios, N.; Koresis, A.; Solis, M.A.B.; Santoni, L.J. COVID-19, aftermath, impacts, and hospitality firms: An international perspective. Int. J. Hosp. Manag. 2020, 91, 102654. [CrossRef]

8. Harney, B.; Collings, D.G. Navigating the shifting landscapes of HRM. Hum. Resour. Manag. R. 2021, 31, 100824. [CrossRef]

9. Wright, P.M. Rediscovering the "Human" in strategic human capital. Hum. Resour. Manag. R. 2021, 31, 100781. [CrossRef]

10. Hu, X.; Yan, H.; Casey, T.; Wu, C.H. Creating a safe haven during the crisis: How organizations can achieve deep compliance with COVID-19 safety measures in the hospitality industry. Int. J. Hosp. Manag. 2021, 92, 102662. [CrossRef]

11. Hewett, R.; Shantz, A. A theory of HR co-creation. Hum. Resour. Manag. R. 2021, 31, 100823. [CrossRef]

12. McMackin, J.; Heffernan, M. Agile for HR: Fine in practice, but will it work in theory? Hum. Resour. Manag. R. 2021, 31, 100791. [CrossRef]

13. Jooss, S.; McDonnell, A.; Conroy, K. Flexible global working arrangements: An integrative review and future research agenda. Hum. Resour. Manag. R. 2021, 31, 100780. [CrossRef]

14. Page, M.J.; McKenzie, J.E.; Bossuyt, P.M.; Boutron, I.; Hoffmann, T.C.; Mulrow, C.D.; Shamseer, L.; Tetzlaff, J.M.; Akl, E.A.; Brennan, S.E. The PRISMA 2020 statement: An updated guideline for reporting systematic reviews. Int. J. Surg. 2021, $88,105906$. [CrossRef] [PubMed]

15. Braun, V.; Clarke, V. Using thematic analysis in psychology. Qual. Res. Psychol. 2006, 3, 77-101. [CrossRef]

16. Du Plessis, A.; Douangphichit, N.; Dodd, P. HRM in relation to employee motivation and job performance in the hospitality industry. J. Int. Bus. Res. Mar. 2016, 1, 12-21. [CrossRef] 
17. Pizam, A.; Shani, A. The nature of the hospitality industry: Present and future managers' perspectives. Anatolia 2009, 20, 134-150. [CrossRef]

18. Kotler, P.; Makens, J.C.; Bowen, J.T.; Baloglu, S. Marketing for Hospitality and Tourism; Pearson Education: Hoboken, NJ, USA, 2018.

19. Davidson, M.C.; McPhail, R.; Barry, S. Hospitality HRM: Past, present and the future. Int. J. Contemp. Hosp. Manag. 2011, 23, 498-516. [CrossRef]

20. Wieczorek-Kosmala, M. COVID-19 impact on the hospitality industry: Exploratory study of financial-slack-driven risk preparedness. Int. J. Hosp. Manag. 2021, 94, 102799. [CrossRef]

21. McIntosh, R.; Goeldner, C.; Ritchie, J. Hospitality and related services. In Tourism: Principles, Practices, Philosophies, 7th ed.; John Wiley and Sons: Hoboken, NJ, USA, 2007; pp. 116-131.

22. Chien, G.C.; Law, R. The impact of the severe acute respiratory syndrome on hotels: A case study of Hong Kong. Int. J. Hosp. Manag. 2003, 22, 327-332. [CrossRef]

23. Wen, Z.; Huimin, G.; Kavanaugh, R.R. The impacts of SARS on the consumer behaviour of Chinese domestic tourists. Curr. Issues Tour. 2005, 8, 22-38. [CrossRef]

24. Kim, S.S.; Chun, H.; Lee, H. The effects of SARS on the Korean hotel industry and measures to overcome the crisis: A case study of six Korean five-star hotels. Asia Pac. J. Tour. Res. 2005, 10, 369-377. [CrossRef]

25. Lee, C.K.; Song, H.J.; Bendle, L.J.; Kim, M.J.; Han, H. The impact of non-pharmaceutical interventions for 2009 H1N1 influenza on travel intentions: A model of goal-directed behavior. Tour. Manag. 2012, 33, 89-99. [CrossRef] [PubMed]

26. Hung, K.K.; Mark, C.K.; Yeung, M.P.; Chan, E.Y.; Graham, C.A. The role of the hotel industry in the response to emerging epidemics: A case study of SARS in 2003 and H1N1 swine flu in 2009 in Hong Kong. Glob. Health 2018, 14, 1-7. [CrossRef]

27. Park, D.; Kim, W.G.; Choi, S. Application of social media analytics in tourism crisis communication. Curr. Issues Tour. 2019, 22, 1810-1824. [CrossRef]

28. Alan, C.; So, S.; Sin, L. Crisis management and recovery: How restaurants in Hong Kong responded to SARS. Inter. J. Hos. Manag. 2006, 25, 3-11. [CrossRef]

29. Pillai, S.G.; Haldorai, K.; Seo, W.S.; Kim, W.G. COVID-19 and hospitality 5.0: Redefining hospitality operations. Inter. J. Hos. Manag. 2021, 94, 102869. [CrossRef]

30. Im, J.; Kim, H.; Miao, L. CEO letters: Hospitality corporate narratives during the COVID-19 pandemic. Inter. J. Hos. Manag. 2021, 92, 102701. [CrossRef]

31. Snell, S.; Bohlander, G.W.; Bohlander, G. Principles of Human Resource Management; South-Western Cengage Learning: Mason, OH, USA, 2010

32. Kusluvan, S.; Kusluvan, Z.; Ilhan, I.; Buyruk, L. The human dimension: A review of human resources management issues in the tourism and hospitality industry. Cornell. Hosp. Q. 2010, 51, 171-214. [CrossRef]

33. Guerrier, Y.; Deery, M. Research in hospitality human resource management and organizational behaviour. Int. J. Hosp. Manag. 1998, 17, 145-160. [CrossRef]

34. Singh, N.; Hu, C.; Roehl, W.S. Text mining a decade of progress in hospitality human resource management research: Identifying emerging thematic development. Int. J. Hosp. Manag. 2007, 26, 131-147. [CrossRef]

35. Sharma, B.; Gursoy, D. HRM practices in hospitality and tourism industry: A review of the literature. In Proceedings of the 8th Advances in Hospitality and Tourism Marketing and Management (AHTMM) Conference, Bangkok, Thailand, 25-29 June 2018

36. Hervie, D.M.; Illés, C.B.; Dunay, A.; Khalife, M.A. Bibliometric analysis of human resource management (HRM) in the hospitality and tourism industry. J. Manag. 2021, 37, 37-59. [CrossRef]

37. Wang, J.; Dagvadorj, A.; Kim, H. Research trends of human resources management in hotel industry: Evidence from south korea by semantic network analysis. Culin. Sci. Hosp. Res. 2021, 27, 68-78. [CrossRef]

38. Hsieh, H.F.; Shannon, S.E. Three approaches to qualitative content analysis. Qual. Health Res. 2005, 15, 1277-1288. [CrossRef]

39. Corbin, J.M.; Strauss, A. Grounded theory research: Procedures, canons, and evaluative criteria. Qual. Sociol. 1990, 13, 3-21. [CrossRef]

40. Hutchison, A.J.; Johnston, L.H.; Breckon, J.D. Using QSR-NVivo to facilitate the development of a grounded theory project: An account of a worked example. Int. J. Soc. Res. Methodol. 2010, 13, 283-302. [CrossRef]

41. Richards, L. Using NVivo in Qualitative Research; Sage: Thousand Oaks, CA, USA, 1999.

42. Lee, M. Evolution of hospitality and tourism technology research from Journal of Hospitality and Tourism Technology: A computer-assisted qualitative data analysis. J. Hosp. Tour. Technol. 2021; in press. [CrossRef]

43. Suryaningtyas, D.; Asna, A. The strategic roles of human resource managers to achieve competitive advantage in hospitality industry. J. Appl. Manag. 2017, 15, 169-175. [CrossRef]

44. Allaberganov, A.; Preko, A.; Mohammed, I. Government commitment to tourism and hospitality sector during COVID-19 pandemic. Tour. Criti. Pract. Theory 2021, 2, 153-169. [CrossRef]

45. Sinkovics, N. Enhancing the foundations for theorising through bibliometric mapping. Int. Mark. Rev. 2016, 33, 327-350. [CrossRef]

46. Van Eck, N.J.; Waltman, L. Software survey: VOSviewer, a computer program for bibliometric mapping. Scientometrics 2010, 84, 523-538. [CrossRef] 
47. Goulding, C. Grounded theory methodology and consumer behaviour, procedures, practice and pitfalls. In NA-Advances in Consumer Research; Hoch, S.J., Meyer, J.R., Eds.; Association for Consumer Research: Provo, UT, USA, 2000; Volume 27, pp. 261-266.

48. Moher, D.; Liberati, A.; Tetzlaff, J.; Altman, D.G.; Group, P. Preferred reporting items for systematic reviews and meta-analyses: The PRISMA statement. PLoS Med. 2009, 6, e1000097. [CrossRef] [PubMed]

49. Baum, T.; Mooney, S.K.; Robinson, R.N.; Solnet, D. COVID-19's impact on the hospitality workforce-new crisis or amplification of the norm? Int. J. Contemp. Hosp. Manag. 2020, 32, 2813-2928. [CrossRef]

50. Shaw, J.B.; Tang, S.F.; Fisher, C.D.; Kirkbride, P.S. Organizational and environmental factors related to HRM practices in Hong Kong: A cross-cultural expanded replication. Int. J. Hum. Resour. Manag. 1993, 4, 785-815. [CrossRef]

51. Genc, K.Y. Environmental factors affecting human resources management activities of Turkish large firms. Int. J. Bus. Manag. 2014, 9, 102-122. [CrossRef]

52. Bowen, J.; Morosan, C. Beware hospitality industry: The robots are coming. Worldw. Hosp. Tour. Themes 2018, 10, 726-733. [CrossRef]

53. Tuomi, A.; Tussyadiah, I.P.; Stienmetz, J. Applications and Implications of Service Robots in Hospitality. Cornell. Hosp. Q. 2021, 62, 232-247. [CrossRef]

54. Qiu, H.; Li, M.; Shu, B.; Bai, B. Enhancing hospitality experience with service robots: The mediating role of rapport building. J. Hosp. Market. Manag. 2020, 29, 247-268. [CrossRef]

55. Seyitoglu, F.; Ivanov, S. Service robots as a tool for physical distancing in tourism. Curr. Issues. Tour. 2021, 24, 1631-1634. [CrossRef]

56. Li, J.; Bonn, M.A.; Ye, B.H. Hotel employee's artificial intelligence and robotics awareness and its impact on turnover intention: The moderating roles of perceived organizational support and competitive psychological climate. Tour. Manag. 2019, 73, 172-181. [CrossRef]

57. Zhang, J.; Xie, C.; Wang, J.; Morrison, A.M.; Coca-Stefaniak, J.A. Responding to a major global crisis: The effects of hotel safety leadership on employee safety behavior during COVID-19. Int. J. Contemp. Hosp. Manag. 2020, 32, 3365-3389. [CrossRef]

58. Karatepe, O.M.; Saydam, M.B.; Okumus, F. COVID-19, mental health problems, and their detrimental effects on hotel employees' propensity to be late for work, absenteeism, and life satisfaction. Curr. Issues Tour. 2021, 24, 934-951. [CrossRef]

59. Rosemberg, M.A.S.; Adams, M.; Polick, C.; Li, W.V.; Dang, J.; Tsai, J.H.C. COVID-19 and mental health of food retail, food service, and hospitality workers. J. Occup. Environ. Hyg. 2021, 18, 169-179. [CrossRef] [PubMed]

60. Abdalla, M.D.J.; Said, H.; Ali, L.; Ali, F.; Chen, X. COVID-19 and unpaid leave: Impacts of psychological contract breach on organizational distrust and turnover intention: Mediating role of emotional exhaustion. Tour. Manag. Perspect. 2021, $39,100854$. [CrossRef] [PubMed]

61. Yorulmaz, M.; Sevinc, F. Supervisor support and turnover intentions of yacht captains: The role of work-family conflict and psychological resilience during the COVID-19 pandemic. Int. J. Contemp. Hosp. Manag. 2021, 33, 1554-1570. [CrossRef]

62. Bajrami, D.D.; Terzic, A.; Petrovic, M.D.; Radovanovic, M.; Tretiakova, T.N.; Hadoud, A. Will we have the same employees in hospitality after all? The impact of COVID-19 on employees' work attitudes and turnover intentions. Int. J. Hosp. Manag. 2021, 94, 102754. [CrossRef] [PubMed]

63. Lee, P.C.; Xu, S.; Yang, W. Is career adaptability a double-edged sword? The impact of work social support and career adaptability on turnover intentions during the COVID-19 pandemic. Int. J. Hosp. Manag. 2021, 94, 102875. [CrossRef]

64. Shah, C.; Chowdhury, A.; Gupta, V. Impact of COVID-19 on tourism and hospitality students' perceptions of career opportunities and future prospects in India. J. Teach. Travel. Tour. 2021, 21, 359-379. [CrossRef]

65. Huang, R.; Xie, C. Pressure, state and pesponse: Configurational analysis of antecedents of hotel employees' career prospect perceptions following the COVID-19 pandemic crisis. Tour. Tribune. 2021, 36, 103-119.

66. Yan, J.; Kim, S.; Zhang, S.X.; Foo, M.D.; Alvarez-Risco, A.; Del-Aguila-Arcentales, S.; Yanez, J.A. Hospitality workers' COVID-19 risk perception and depression: A contingent model based on transactional theory of stress model. Int. J. Hosp. Manag. 2021, $95,102935$. [CrossRef]

67. Tsui, P.L. Would Organizational Climate and Job Stress Affect Wellness? An Empirical Study on the Hospitality Industry in Taiwan during COVID-19. Int. J. Environ. Res. Public Health 2021, 18, 10491. [CrossRef] 